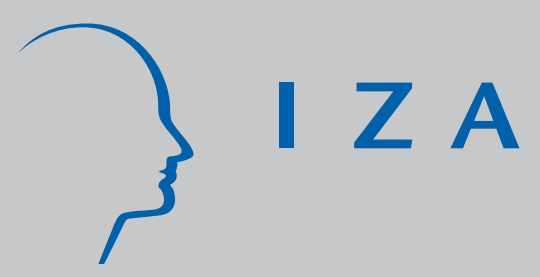

IZADP No. 3423

Migration and the Wage Curve: A Structural Approach to Measure the Wage and Employment Effects of Migration

Herbert Brücker

Elke J . J ahn

March 2008 


\title{
Migration and the Wage Curve: A Structural Approach to Measure the Wage and Employment Effects of Migration
}

\author{
Herbert Brücker \\ University of Bamberg, \\ $I A B$ and IZA \\ Elke J. Jahn \\ University of Århus, \\ $I A B$ and IZA
}

\author{
Discussion Paper No. 3423 \\ March 2008
}

\author{
IZA \\ P.O. Box 7240 \\ 53072 Bonn \\ Germany \\ Phone: +49-228-3894-0 \\ Fax: +49-228-3894-180 \\ E-mail: iza@iza.org
}

\begin{abstract}
Any opinions expressed here are those of the author(s) and not those of IZA. Research published in this series may include views on policy, but the institute itself takes no institutional policy positions.

The Institute for the Study of Labor (IZA) in Bonn is a local and virtual international research center and a place of communication between science, politics and business. IZA is an independent nonprofit organization supported by Deutsche Post World Net. The center is associated with the University of Bonn and offers a stimulating research environment through its international network, workshops and conferences, data service, project support, research visits and doctoral program. IZA engages in (i) original and internationally competitive research in all fields of labor economics, (ii) development of policy concepts, and (iii) dissemination of research results and concepts to the interested public.
\end{abstract}

IZA Discussion Papers often represent preliminary work and are circulated to encourage discussion. Citation of such a paper should account for its provisional character. A revised version may be available directly from the author. 


\section{ABSTRACT}

\section{Migration and the Wage Curve: A Structural Approach to Measure the Wage and Employment Effects of Migration ${ }^{*}$}

Based on a wage curve approach we examine the labor market effects of migration in Germany. The wage curve relies on the assumption that wages respond to a change in the unemployment rate, albeit imperfectly. This allows one to derive the wage and employment effects of migration simultaneously in a general equilibrium framework. For the empirical analysis we employ the IABS, a two percent sample of the German labor force. We find that the elasticity of the wage curve is particularly high for young workers and workers with a university degree, while it is low for older workers and workers with a vocational degree. The wage and employment effects of migration are moderate: a 1 percent increase in the German labor force through immigration increases the aggregate unemployment rate by less than 0.1 percentage points and reduces average wages by less 0.1 percent. While native workers benefit from increased wages and lower unemployment, foreign workers are adversely affected.

JEL Classification: $\quad$ F22, J31, J61

Keywords: migration, wage curve, labor demand, panel data

Corresponding author:

Elke J. Jahn

Department of Economics

Aarhus School of Business

University of Aarhus

Prismet, Silkeborgvej 2

DK-8000 Aarhus C

Denmark

E-mail: elja@asb.dk

\footnotetext{
* The authors are grateful to Thomas Büttner, who imputed the wage data for the empirical part of this paper, and to Andreas Hauptmann, who programmed the code of the simulation model. Gabriel Felbermayr, Peter Huber, Wilhelm Kohler, Michael E. Landesmann, Rainer Münz, Philipp J.H. Schröder, Alessandra Venturini and the participants of the Thyssen-Workshop on migration at the University of Tübingen, December 7-8, 2007 provided valuable comments. Herbert Brücker gratefully acknowledges financial support from the European Commission granted to the "Transnationality of Migrants" project. The usual disclaimer applies.
} 


\section{Introduction}

High and increasing immigration rates in the US and Europe have fanned fears that migrants reduce wages and harm employment opportunities of the native labor force. Concerns that immigration increases unemployment are particularly widespread in the continental European countries, where unemployment is high and persisting. In this paper we apply an aggregate wage curve approach to analyze the labor market effects of immigration. The wage curve relies on the assumption that wages respond to changes in the unemployment rate, albeit imperfectly. This allows us to consider institutional and other labor market rigidities, which are particularly relevant in the European context. In contrast to the overwhelming majority of the empirical literature, which addresses the impact of migration on wages and (un-)employment separately, we analyze the wage and employment effects of migration simultaneously in a general equilibrium framework.

Following the seminal contributions of Borjas (2003) and Ottaviano and Peri (2006), we employ a nested production function which assumes that migrant and native workers within the same experience and education group are imperfect substitutes. We also consider the imperfect adjustment of capital stocks. Since it is likely that the bargaining power of workers and employers varies in the different segments of the labor market, we allow the wage curve to differ across education and experience groups.

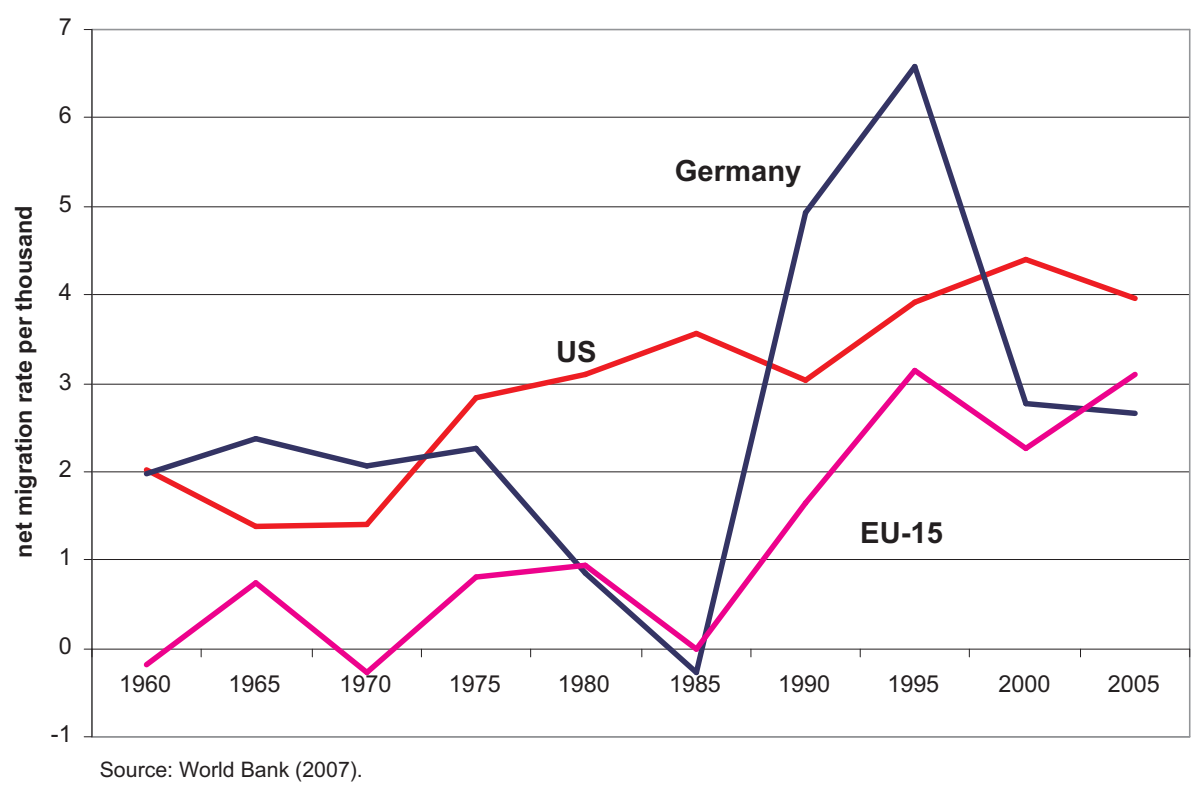

Figure 1: Net migration rate per thousand, 1960-2005 
We apply this framework empirically to Germany, which is the third most popular destination for migrants in the world after the US and Russia (Freeman, 2006). With the fall of the Berlin wall, the net immigration rate climbed in Western Germany from about zero at the beginning of the 1980 s to about 6 per thousand at the beginning of the 1990s, compared to 3 per thousand in the fifteen member states of the then European Union (EU-15) and 4 per thousand in the US (World Bank, 2007). Three main groups have contributed to this immigration surge: foreigners from Central and Eastern Europe and the former Yugoslavia, ethnic Germans (so-called "Spätaussiedler"), and East Germans. However, since the beginning of this millennium, the net immigration rate has dropped to less than 3 per thousand in the course of Germany's economic downturn (Figure 1).

Our empirical analysis is based on a 2 percent sample of the German labor force (IABS) which is derived from social security records. The IABS provides detailed information on education and experience of employed and unemployed individuals in the labor force. This data set allows us to identify the elasticities of the wage curve for education and experience groups and to estimate the elasticities of substitution between different types of labor in Western Germany in the period from 1980 to 2004.

We find an average elasticity of the wage curve of -0.12 at the national level, which is slightly higher than the elasticities found in regional level studies in other OECD countries (see Blanchflower and Oswald, 1994a; Card, 1995; Nijkamp and Poot, 2005), but substantially higher than that found at the regional level in Germany. However, the elasticities of the wage curves fluctuate considerably across skill groups and experience groups. Labor market flexibility is particularly high for highly educated workers and workers with little work experience.

At the given skill structure of the foreign workforce, a 1 percent increase in labor supply through the immigration of foreigners increases the unemployment rate by less than 0.1 percentage points in the short run, while it remains stable in the long run. Average wages decline by less than 0.1 percent. While native workers tend to benefit from higher wages and lower unemployment risks, wages of the foreign labor force decline by about 0.5 percent and the unemployment rate increases by about 0.3 percentage points in the short run and by 0.1 percentage points in the long run. Interestingly enough, for the labor supply shock during the period 1980-2004, we find that immigration reduces unemployment in the short run. This can be traced back to the fact that wages do not completely adjust to labor demand changes. The employment gains in a segment with relatively low wage flexibility can therefore more than compensate for losses in labor market segments with higher wage flexibility. However, this effect disappears in our simulations 
when wages have adjusted to their long-run levels.

The remainder of the paper is organized as follows: Section 2 reviews the empirical literature on the wage and employment effects of immigration. Section 3 outlines the model. Section 4 describes the dataset. Section 5 presents the identification strategy and the estimation results for the elasticities of the wage curves, the capital stock adjustment, and the elasticities of the production function. Section 6 simulates the employment and wage impact of immigration on the German labor market. Finally, Section 7 concludes.

\section{Review of the literature}

Despite a large number of careful studies, the empirical literature has produced mixed evidence regarding the wage and employment effects of migration. The overwhelming share of this literature uses the variance of foreigner shares across regions for the identification of the wage and employment effects of migration. Although the findings of this literature vary from study to study, both the wage and the employment effects of migration seem to cluster around zero (see the surveys and meta-studies by Friedberg and Hunt, 1995; Longhi, Nijkamp, and Poot, 2005, 2006). This spatial correlation approach may yield spurious results if migrants are not randomly distributed across locations. Moreover, the adjustment of other labor or capital flows may equilibrate the migration effects across regions. This literature therefore either relies on natural experiments (e.g. Card, 1990; Carrington and DeLima, 1996; Hunt, 1992) or uses instrumental variable estimators to correct for the endogeneity of locational choices of migrants (e.g. DeNew and Zimmermann, 1994; Haisken-DeNew and Zimmermann, 1995; Mühleisen and Zimmermann, 1994; Ottaviano and Peri, 2005a,b; Pischke and Velling, 1997). It nevertheless remains controversial whether the wage and employment effects of migration can be properly identified by spatial correlations between migration shares and labor market outcomes. ${ }^{1}$

The spatial correlation approach has been challenged in an influential paper by Borjas (2003) which exploits the variance of the foreigner share across education and experience groups at the national level to identify the wage effects of migration. Under the assumption that the education and experience characteristics of the migrant workforce are exogenous, this allows an unbiased estimation of the labor market effects of migration. Borjas (2003) measures the elasticities between wages and labor supply shocks in the different education and experience cells of the US labor market and finds an

\footnotetext{
${ }^{1}$ See Card (2001), Borjas, Freemann, and Katz (1997) and Borjas (2003) for controversial arguments and evidence.
} 
elasticity of between -0.3 and -0.4 , which implies that a 10 percent increase of the labor force through migration reduces wages by 3 to 4 percent. Aydemir and Borjas (2007) obtain the same elasticities for Canada and Mexico. Based on a similar approach Bonin (2005) however finds that an immigration of 10 percent reduces wages by less than 1 percent in Germany.

Ottaviano and Peri (2006) however find in a national-level framework results which are comparable to those of the spatial-correlation studies. Employing the same dataset as Borjas (2003) they find that immigration has increased native wages on average in the US, while wages of foreigners tend to decline substantially. Two aspects set their approach apart from the Borjas (2003) study: first, they provide evidence that native and foreign workers within the same education and experience cell of the labor market are imperfect substitutes, while Borjas (2003) assumes perfect substitutionality. ${ }^{2}$ Second, they consider the adjustment of capital stocks, while Borjas (2003) treats the physical capital stock as fixed - in line with the overwhelming majority of the literature. ${ }^{3}$ Ottaviano and Peri (2006) find that a one percent increase of the labor force through immigration increases native wages by 0.06 percent under the assumption of a fixed capital stock and by 0.16 percent under the assumption of complete capital stock adjustment, while the wages of the foreign-born workforce decline by about 2.1 percent in the short run and by about 1.8 percent in the long run.

Borjas (2003) and Ottaviano and Peri (2006) focus on wages and rely implicitly on the assumption that labor markets clear. The application of this approach is particularly questionable in the case of economies that are characterized by wage rigidities and involuntary unemployment. There exists a large literature which analyzes the effects of migration on employment opportunities of natives (see Bonin, 2005; Borjas, Grogger, and Hanson, 2006; Hatizius, 1994; Mühleisen and Zimmermann, 1994; Pischke and Velling, 1997; Longhi, Nijkamp, and Poot, 2006, for a meta-analysis). This literature treats the wage and employment effects of migration separately, however, ignoring the interactions between wage rigidities and the employment effects of migration. ${ }^{4}$

This is the aspect in which the present paper contributes to the state of

\footnotetext{
${ }^{2}$ Aydemir and Borjas (2007), however, could not replicate these results. They found that native and foreign workers are perfect substitutes in the US and Canadian labor markets, confirming earlier results by Jaeger (1996) for the US.

${ }^{3}$ Aydemir and Borjas (2007) relax this assumption by applying a similar approach to Ottaviano and Peri (2006) for the adjustment of the capital stock.

${ }^{4}$ The Borjas, Grogger, and Hanson (2006) paper, which considers the impact of wages on the decision to participate in labor markets and in criminal activities, may be regarded as an exception in this context, although it still assumes that wages are perfectly flexible.
} 
the literature. We address the labor market effects of migration in a framework where wages and employment are simultaneously determined. Following the wage curve literature (Blanchflower and Oswald, 1994a, 1995), we assume that an equilibrium relationship exists between the wage level and the unemployment rate. This sets the wage curve apart from the Phillips (1958) curve, which relates the growth rate of wages to the unemployment rate and considers this relationship as a disequilibrium phenomenon. ${ }^{5}$

We estimate the wage curve at the national level. This distinguishes our approach from the traditional wage curve literature, which uses the variance across regions for the identification of the wage curve. The macroeconomic relationship between the wage and the unemployment rate is sometimes labeled as a 'wage setting curve' (Blanchard, 2003) or 'aggregate wage curve' (Blanchflower and Oswald, 2005). Starting with Sargan (1964), there exist a number of studies that empirically examine the relation between the wage and unemployment rate at the national level (see e.g. Guichard and Laffargue, 2000, for a recent contribution). Card (1995) presents empirical evidence for the US that a wage curve exists at the national level that displays similar elasticities to those found by Blanchflower and Oswald (1994a) at the regional level.

In our view it is appropriate to estimate the wage curve at the national level if centralized wage setting plays - as in Germany - an important role. In this case regions do not form independent labor market units. Consequently, regional level studies may understate the elasticity between wages and unemployment. Interestingly enough, we find an elasticity of the wage curve at the national level which is substantially larger than that found in a recent regional level study for Germany employing a similar data set (Baltagi, Blien, and Wolf, 2007).

D'Amuri, Ottaviano, and Peri (2008) and Felbermayr, Geis, and Kohler (2008) recently applied the Ottaviano and Peri (2006) approach to the analysis of the labor market impact of immigration in Germany. Both papers highlight the importance of wage rigidities for an assessment of the labor market effects of migration. However, the empirical framework of these papers follows the standard approach of the existing literature in estimating separate employment equations, while we apply a structural approach that determines employment and wages simultaneously in a general equilibrium framework.

\footnotetext{
${ }^{5}$ Bentolila, Dolado, and Jimeno (2007) examine the effects of immigration in a Phillips curve framework. This paper addresses the question of whether immigration has changed the slope of the Phillips curve in Spain, while we assume - based on the existing empirical evidence - that the slope of the wage curve is rather stable over time.
} 


\section{Theoretical background}

The model builds on Boeri and Brücker (2005) and Levine (1999) in deriving the wage and employment effects of migration from a wage curve. While these papers focus on the aggregate effects of migration, we group the labor force by education, experience, and nationality here. Similar to Borjas (2003) and Ottaviano and Peri (2006) we follow Card and Lemieux (2001) in employing a nested CES production function for this purpose.

The wage curve can be based on different theoretical foundations (see Blanchflower and Oswald, 1994a; Layard, Nickell, and Jackman, 1991, for a discussion). In our context, two modeling traditions are particularly important. First, the wage curve can be derived from bargaining models (see e.g. Lindbeck, 1993; Layard and Nickell, 1986), which assume that trade unions are concerned about both their employed and unemployed members. Consider the case where wages are fixed in a bilateral bargaining monopoly between trade unions and employer federations. Once wages are fixed, firms hire workers until the marginal product of labor equals the wage rate. Both parties are aware of this. Consequently, the negotiated wage is lower when unemployment is higher and vice versa.

Second, in a completely non-unionized environment, the wage curve can be explained by efficiency-wage considerations (Shapiro and Stiglitz, 1984), where the productivity of workers is linked to the wage level. Unemployment works here as disciplining device since it determines the difficulties in finding a new job. As a result, firms will reduce the remuneration of workers if the unemployment rate is increasing since they can achieve the same level of productivity at a lower wage.

Both approaches have in common that they replace the conventional labor supply curve with a wage fixing function and that they rely on standard assumptions about labor demand (Blanchflower and Oswald, 1995; Layard and Nickell, 1986). However, different conclusions regarding the shape of the wage curve emerge from these different theoretical foundations: on the one hand, the bargaining model predicts a flatter wage curve in labor market segments with a higher share of unionized workers. The share of unionized workers is exceptionally high among workers with a vocational training degree in Germany, i.e., among workers with a medium skill level. On the other hand, the efficiency wage model expects a flatter wage curve for workers with a higher level of firm-specific human capital, since firm-specific human capital drives a wedge between productivity at the current employer and the outside opportunity wages, thereby allowing employers to "smooth" wages across the business cycle (Card, 1995). Thus, it is likely that the wage curve is flatter for high-skilled workers since they tend to acquire greater levels of 
firm-specific human capital.

Therefore we do not derive the wage curve from a specific wage bargaining or efficiency wage model here. We instead assume that a wage-fixing mechanism exists, which responds to the unemployment rate, albeit imperfectly. Following Card (1995), we allow the wage curve to vary for different groups of the labor force. Once wages are fixed, profit-maximizing firms hire workers until the marginal product of labor equals the wage rate. This approach allows us to derive the employment and wage response to an exogenous labor supply shock in a general equilibrium framework. The elasticities of the production function and of the wage curve determine a system of simultaneous equations that can be solved analytically.

\subsection{A structural approach to immigration and unem- ployment}

Suppose that the aggregate output of an economy is produced with different types of labor and physical capital. In general form, we can write the aggregate production function as

$$
Y=F(\mathbf{L}, K)
$$

where $Y$ denotes aggregate output, $\mathbf{L}$ a vector of different types of labor inputs, and $K$ the capital stock. We assume that the production function $F(\cdot)$ exhibits constant returns to scale and positive and diminishing marginal products with respect to each input, and satisfies the Inada (1963)-conditions. For the sake of convenience we have skipped time subscripts.

We distinguish labor inputs by education, experience, and nationality. Wages and the demand for labor are determined sequentially. In the first stage, wages are fixed. The elasticity of the wage with respect to the unemployment rate may differ in each cell of the labor market depending on the bargaining power of the partners in the wage negotiations or the level of specific human capital. In the second stage, profit-maximizing firms hire workers until the marginal product of labor equals the wage rate.

Writing the wage in each cell of the labor market as a function of the respective unemployment rate gives

$$
w_{i j k}=\phi_{i j k}\left(u_{i j k}\right), \quad \phi_{i j k}^{\prime}<0,
$$

where $w_{i j k}$ is the wage of a worker with education $i$, experience $j$ and national origin $k, \phi_{i j k}$ is a function which captures the response of the wage to the 
unemployment rate. The unemployment rate $u_{i j k}$ is defined as

$$
u_{i j k}=1-\frac{L_{i j k}}{N_{i j k}}
$$

where $L_{i j k}$ and $N_{i j k}$ denote the employed workforce and the labor force of education $i$, experience $j$ and national origin $k$, respectively.

The condition that the wage rate in equation (2) equals the marginal product of labor allows us to solve for the employment response to a change in labor supply. Note that the marginal product of labor in a specific education, experience, and national origin cell of the labor market is affected by the employment changes in all other cells of the labor market. Solving for the employment response thus requires solving a system of equations for all other cells of the labor market, which is determined by the wage curves and the production function. This system has to satisfy in each cell of the labor market the implicit function

$$
\Phi_{i j k}=w_{i j k}(\mathbf{L}, K)-\phi_{i j k}\left(u_{i j k}\right)=0, \quad \forall i j k .
$$

Differentiating this system implicitly with respect to a marginal migration shock yields for the change in employment

$$
\frac{d \mathbf{L}}{d M}=\left(\frac{\partial \mathbf{w}}{\partial \mathbf{L}}-\frac{\partial \phi}{\partial \mathbf{u}} \frac{\partial \mathbf{u}}{\partial \mathbf{L}}\right)^{-1} \times\left(\frac{\partial \phi}{\partial \mathbf{u}} \frac{\partial \mathbf{u}}{\partial \mathbf{N}} \frac{d \mathbf{N}}{d M}-\frac{\partial \mathbf{w}}{\partial K} \frac{d K}{d M}\right),
$$

where $d M$ is a scalar which captures the marginal immigration shock to the economy, $\phi$ a vector of functions which determine as above the wage response to the unemployment rate, and $\mathbf{N}$ a vector of the labor force in each cell of the labor market. We assume here that the capital stock may adjust to a labor supply shock through migration, i.e., that $\frac{d K}{d M} \geq 0$.

Equation (4) has an economic interpretation. Consider two extreme cases: first, assume that labor markets are completely flexible, which requires that $\phi_{i j k}^{\prime} \rightarrow-\infty \forall \phi_{i j k}$. In this case equation (4) simplifies to

$$
\frac{d \mathbf{L}}{d M} \rightarrow \frac{d \mathbf{N}}{d M},
$$

i.e., the marginal employment response equals the marginal increase in the labor force in each cell of the labor market. This case corresponds to the textbook example of the impact of migration in an economy with clearing labor markets and an inelastic supply of native labor (e.g. Wong, 1995, pp. 628-632). 
Second, assume that labor markets are completely inflexible, i.e., that $\phi_{i j k}^{\prime} \rightarrow 0 \forall i j k$. In this case equation (4) yields

$$
\frac{d \mathbf{L}}{d M} \rightarrow\left(\frac{\partial \mathbf{w}}{\partial \mathbf{L}}\right)^{-1} \times\left(-\frac{\partial \mathbf{w}}{\partial K} \frac{d K}{d M}\right),
$$

which equals zero if the capital stock does not adjust to the labor supply shock. This case corresponds to the famous Harris and Todaro (1970) model.

In the empirically relevant case, i.e., when $0>\phi_{i j k}^{\prime}>-\infty$, employment adjusts partially to a labor supply shock through migration, depending on the elasticities of the wage curve and the elasticities of substitution as determined by the production function.

Finally, having solved for the employment response, it is straightforward to derive the wage effects of migration:

$$
\frac{d \mathbf{w}}{d M}=\frac{\partial \mathbf{w}}{\partial \mathbf{L}} \frac{d \mathbf{L}}{d M}+\frac{\partial \mathbf{w}}{\partial K} \frac{d K}{d M}
$$

\subsection{Outline of the empirical framework}

For the empirical analysis we have to impose more structure on the economy. We follow Borjas (2003) and Ottaviano and Peri (2006) in assuming that the production function can be approximated by nested CES technologies. The aggregate workforce is decomposed in $i=1 \ldots 4$ education groups, $j=1 \ldots 8$ experience groups, and $k=1,2$ nationality groups, which gives together with physical capital 65 production factors. Although the nested CES function imposes some restrictions on the elasticities of substitution, it has the advantage that it is parsimonious in the parameters. Note that a general specification of the production technologies, such as the translog function, would require estimating 2,016 different parameters of the production function in our case.

Supposing that the aggregate production function in equation (1) can be represented by standard Cobb-Douglas technologies yields

$$
Y_{t}=A_{t} L_{t}^{\alpha} K_{t}^{1-\alpha}
$$

where $Y_{t}$ denotes aggregate output, $A_{t}$ total factor productivity, $L_{t}$ the aggregate labor input, $K_{t}$ physical capital, $\alpha$ the income share of labor, and $t$ the time index. Assuming a constant elasticity of substitution across education groups gives for the composite labor input

$$
L_{t}=\left[\sum_{i=1}^{4} \theta_{i t} L_{i t}^{(\delta-1) / \delta}\right]^{\delta /(\delta-1)}, \quad \sum_{i=1}^{4} \theta_{i t}=1
$$


where $L_{i t}$ is an aggregate measure for the employed workforce with education $i, \theta_{i t}$ a skill-specific productivity level and $\delta>0$ a constant parameter which determines the elasticity of substitution between labor of different education levels. We assume the productivity parameter $\theta_{i t}$ to vary over time since skill-biased technological progress might affect the productivity of various types of labor in different ways.

Analogously, each labor input $L_{i t}$ is defined as

$$
L_{i t}=\left[\sum_{j=1}^{8} \theta_{i j} L_{i j t}^{(\rho-1) / \rho}\right]^{\rho /(\rho-1)}, \quad \sum_{j=1}^{8} \theta_{i j}=1,
$$

where $L_{i j t}$ denotes an aggregate measure for employed workers of skill group $i$ and experience group $j, \theta_{i j t}$ a productivity parameter, and $\rho>0$ a parameter which determines the elasticity of substitution of labor with similar education but different experience.

Finally, the employment within each education and experience cell is given by an aggregation of native and foreign workers with similar education and experience, i.e., by

$$
L_{i j t}=\left[\sum_{k=1}^{2} \theta_{i j k} L_{i j k t}^{\left(\sigma_{i}-1\right) / \sigma_{i}}\right]^{\sigma_{i} /\left(\sigma_{i}-1\right)}, \quad \sum_{k=1}^{2} \theta_{i j k}=1,
$$

where $L_{i j k t}$ denotes workers of skill group $i$, experience group $j$, and national origin $k, \theta_{i j k}$ a productivity parameter, and $\sigma_{i}$ a parameter which determines the elasticity of substitution between native and foreign workers.

We allow $\sigma_{i}$ to differ across education groups, assuming that the elasticity of substitution between native and foreign workers varies across education groups given that the importance of language, culture, and other factors may differ by education.

Our a priori expectation is that workers within each education and experience group are closer substitutes than those across education and experience groups, which implies that $\sigma_{i}>\rho$, and that workers within the same skill group are closer substitutes than those across skill groups, which implies that $\rho>\delta$.

Assuming that the wage rate equals the marginal product of labor and choosing output as the numeraire good, we can derive from the production function the log wage of a worker of skill $i$, education $j$, and national origin 
$k$ as

$$
\begin{aligned}
\ln w_{i j k t} & =\ln \left(\alpha A_{t}^{1 / \alpha}\right)+\frac{1}{\delta} \ln L_{t}+\ln \theta_{i t}-\left(\frac{1}{\delta}-\frac{1}{\rho}\right) \ln L_{i t} \\
& +\ln \theta_{i j}-\left(\frac{1}{\rho}-\frac{1}{\sigma_{i}}\right) \ln L_{i j t}+\ln \theta_{i j k}-\frac{1}{\sigma_{i}} \ln L_{i j k t}+\frac{1-\alpha}{\alpha} \ln \kappa_{t},
\end{aligned}
$$

where $\kappa$ denotes the capital-output ratio.

The interest rate is a function of the capital-output ratio, i.e., $r=\frac{1-\alpha}{\kappa}$. Thus, the complete adjustment of the capital stock to an aggregate labor supply shock requires that the capital-output ratio remains constant. Note that a constant capital-output ratio is predicted by neoclassical growth models and one of the stylized facts about economic growth (Kaldor, 1961). Following Ottaviano and Peri (2006) we assume that $\frac{d \kappa}{d M} \leq 0$, which is examined below.

The derivatives of equation (10) are used for finding the partial derivatives of the wage with respect to the labor supply changes in equation (4). For an explicit solution of the employment response, see the Appendix.

Finally, having solved for the employment response we can express the wage effect of migration in equation (5) as

$$
\begin{aligned}
\frac{d w_{i j k t}}{w_{i j k t}} & =\frac{1}{\delta} \sum_{q} \sum_{n} \sum_{m}\left(s_{q n m t} \frac{d L_{q n m t}}{L_{q n m t}}\right)_{\text {immigration }} \\
& -\left(\frac{1}{\delta}-\frac{1}{\rho}\right) \frac{1}{s_{i t}} \sum_{n} \sum_{m} s_{\text {inmt }}\left(\frac{d L_{\text {inmt }}}{L_{\text {inmt }}}\right)_{\text {immigration }} \\
& -\left(\frac{1}{\rho}-\frac{1}{\sigma_{i}}\right) \frac{1}{s_{i j t}} \sum_{m}\left(s_{i j m t} \frac{d L_{q k j t}}{L_{q k j t}}\right)_{\text {immigration }} \\
& -\sigma_{i}\left(\frac{d L_{i j k t}}{L_{i j k t}}\right)_{\text {immigration }}+\frac{(1-\alpha)}{\alpha}\left(\frac{d \kappa_{t}}{\kappa_{t}}\right)_{\text {immigration }},
\end{aligned}
$$

where $s_{q n m t}, s_{i n m t}, s_{i j m t}, s_{i j t}$ and $s_{i t}$ denote the share of the wages paid to workers in the respective labor market cells in the total wage bill. ${ }^{6}$ The terms in brackets include the response of employment to migration as determined by equation (4) as well as the response of the capital-output ratio to migration.

Note that the assumption that the wage rate equals the marginal product of labor results in a similar equation for the factor demand to the equations

\footnotetext{
${ }^{6}$ Thus, $s_{i j k t}=\frac{w_{i j k t} L_{i j k t}}{\sum_{q} \sum_{n} \sum_{m} w_{q n m t} L_{q n m t}}, s_{i j t}=\frac{\sum_{m} w_{i j m t} L_{i j m t}}{\sum_{q} \sum_{n} \sum_{m} w_{q n m t} L_{q n m t}}$, and $s_{i t}=$ $\frac{\sum_{n} \sum_{m} w_{i n m t} L_{i n m t}}{\sum_{q} \sum_{n} \sum_{m} w_{q n m t} L_{q n m t}}$.
} 
found in the existing literature. Thus we can compare our findings regarding the wage effects of a marginal employment shock inter alia with those of Borjas (2003) and Ottaviano and Peri (2006).

\section{Data}

\subsection{Description of the dataset}

In our empirical analysis we use the IAB Sample (IABS), a two percent random sample of all German employees registered with the social security system covering the period 1975-2004. The IABS provides information on socio-economic and job characteristics at the individual level. Supplementary information on benefit recipients is added to the sample. The IABS is stratified according to nationality and therefore representative for the native and foreign working population.

Being of an administrative nature, the IABS provides longitudinal information on the employment and unemployment history of employees. Each employment and unemployment spell contains a starting and an ending date and provides accurate information on the timing of transitions between unemployment and employment. Reported wages are used to calculate social security contributions of the employers and are highly reliable. Hence the dataset is especially suitable for performing analyses taking wages into account.

Nevertheless the IABS has also some limitations in the context of our analysis: the main shortcoming is that we can identify foreigners only on the basis of citizenship. There is no information on the year when immigrants entered the country. This has several implications. First, due to the jus sanguinis tradition of the German law, naturalization rates have been traditionally very low, such that second and third generation migrants often still have foreign citizenship and are therefore recorded as foreign workers in our sample. On August 1, 1999, a new immigration act came into effect that allows German-born children of foreign-born parents living for at least eight years in Germany to decide up to the age of 23 which nationality to adopt. This has substantially increased the naturalization of German-born individuals whose parents have a migrant background. Our dataset may therefore suffer from a structural break.

To mitigate the possible effects of naturalizations, we have classified all individuals as foreigners who are reported as foreign citizen in their first available spell. This does not allow us to control for individuals who are naturalized before entering the sample, but avoids naturalizations from being 
displayed in our sample as a declining foreigner share.

Second, ethnic Germans - so-called "Spätaussiedler" - are reported in the dataset as Germans, since the concept of citizenship does not allow us to distinguish between home and foreign-born German citizens. However, special benefits have been offered to ethnic Germans, such as language courses and other integration subsidies that should facilitate labor market integration, and these measures are reported in the benefit recipient file added to our dataset. This allows us to identify the overwhelming share of ethnic Germans who have entered the German labor force since 1980. Since ethnic Germans' labor market performance and language command resembles that of other foreigners (see e.g. Bauer and Zimmermann, 1997; Zimmermann, 1999), we have classified ethnic Germans as members of the foreign labor force.

Third, Eastern Germany is not covered by the IABS before 1992. We can therefore only identify migrants from Eastern Germany if they appear the first time in the dataset after 1992 and if their first spell indicates that they reside in Eastern Germany. A large number of East-West migrants moved to Western Germany before appearing as employed or unemployed in the dataset, e.g., as students (Burda and Hunt, 2001; Hunt, 2006). Moreover, a large part of the East-West migrants in Germany cannot be identified since more than one-third of the two million migrants from Eastern Germany moved to Western Germany immediately after the fall of the Berlin wall, i.e., before German reunification in October 1990 (Bundesamt, 2006).

The dataset thus captures only part of this immigration surge. Moreover, those individuals who can be identified as East Germans have different education and experience characteristics than those individuals from Eastern Germany who we cannot identify. We thus classify East Germans here as natives. Treating East-West migrants as natives is appropriate in our view since individuals from Eastern Germany share the same language and cultural background with individuals who have grown up in Western Germany. Not surprisingly, the labor market performance of East-West migrants is similar or even slightly better than that of West Germans if we control for education and experience (Brücker and Trübswetter, 2007).

There are moreover other features of the dataset that may affect our analysis. First, the employment history of individuals is interrupted if jobseekers are not eligible for unemployment benefits, unemployment assistance, or maintenance allowance. This implies that individuals are considered to be out of the labor force and are therefore not covered in the sample although they might be looking for a job. From administrative data sources of the Federal Employment Agency we know that about 90 percent of the registered unemployed are eligible for benefits. Therefore the unemployment rate is only 
slightly biased downwards (Wagner and Jahn, 2004).

Second, self-employed workers and civil servants do not contribute to the social security system and are therefore not covered by our sample. To the best of our knowledge there is no indication that foreign workers are disproportionally self-employed compared to native workers. In the case of civil servants, it seems plausible to assume that due to legal restrictions, immigrants do not substitute natives.

Third, our data are right-censored since gross wages can only be observed up to the social security contribution ceiling. About three percent of the employment spells are censored. This may affect the estimation of the wage curves particularly in the high-skilled segments of the labor market. We have therefore imputed wages above the social security contribution ceiling using a heteroscedastic single imputation approach specifically developed for the IABS data set (Büttner and Rässler, 2007). The regression is run separately for each year and according to nationality for Western German employees. In addition we included the following variables: age, age squared, six educational groups, industry codes, four variables for the occupational status, and ten occupational variables, classifying the actual position held by the worker.

Fourth, the dataset reports gross daily wages and does not provide information on the hours worked. We therefore exclude part-time employees, marginal employees, trainees, interns and home-workers from the sample since the wage information is not accurate for these groups. For the same reason we exclude workers with wages below the social security contribution threshold although they are coded as full time workers. These workers are likely to hold a "mini job". Their income is exempted from the social security contributions up to threshold which is adjusted on a sporadic basis (400 euros per month in 2007). There is no indication that this creates a source of bias in the empirical analysis since foreigners are proportionally represented in the respective groups.

Fifth, we restrict our analysis to full-time employees between the ages of 15 and 60 . The reasons are that the statutory retirement age for females is the age of 60 , for males the age of 65 . In addition, there is some empirical evidence of differences in early retirement behavior between German and immigrant men (Bonin, Raffelhüschen, and Walliser, 2000).

We focus in our analysis on Western Germany, since Eastern Germany is not included in the IABS before 1992. Note that the foreigner share in Eastern Germany is almost negligible. German reunification also requires excluding Western Berlin, since mobility between Eastern and Western Berlin has been high since the fall of the wall. Furthermore, local employment offices in Berlin were pooled, which prevents us from clearly distinguishing between unemployed workers in Western and Eastern Berlin since reunification. 
Following the model outlined in Section 3, we group the labor force by education and potential work experience. A sensible classification following the characteristics of the German labor market requires us to distinguish four education groups: no vocational degree, vocational degree, a high school degree ("Abitur") with a vocational training degree, and a university degree. The group with a university degree also covers individuals with a degree from a university of applied sciences ("Fachhochschule"). Furthermore we distinguish eight potential work experience classes following the standard approach by Borjas (2003) in subtracting the typical number of years spent in the educational system from the age of the worker and splitting the experience in intervals of five years. At the beginning of the sample period, we have only a few observations in some education experience classes. Therefore, we exclude the 1975 - 1979 period and confine our analysis to individuals who where employed or unemployed on September 30 during the period from 1980 to 2004 (Table 1).

Table 1 about here

The information on education is provided by the employers in the IABS. This means that information on education levels is missing for about 17 percent of the individuals. Foreigners are disproportionally affected by missing information on education levels. We therefore imputed the missing information on education by employing the procedure developed by Fitzenberger, Osikominu, and Völter (2005) for an earlier version of the IABS. In a first step, spells with valid and invalid educational information are identified by classifying the reliability of employers' reporting behavior. In subsequent steps, only valid education information is used for extrapolation. This procedure also allows us to correct inconsistent education information on individuals over time. After applying this imputation procedure, we had to drop only 1.5 percent of the individuals because of missing or inconsistent information on education.

Education and work experience acquired in foreign countries may not have the same value in the labor market as education and experience acquired in Germany. Moreover, certain characteristics of foreigners, such as their command of the German language, may prevent them from fully transferring acquired human capital to the German labor market. However, correcting for the acquired education and experience levels of foreigners by variables which are related to their labor market performance in Germany involves an endogeneity problem. It may moreover bias our estimates of the elasticity 
of substitution between native and foreign workers. We therefore employ the same rules for the classification of education and experience groups for foreign and native workers.

\subsection{Immigration trends and descriptive evidence}

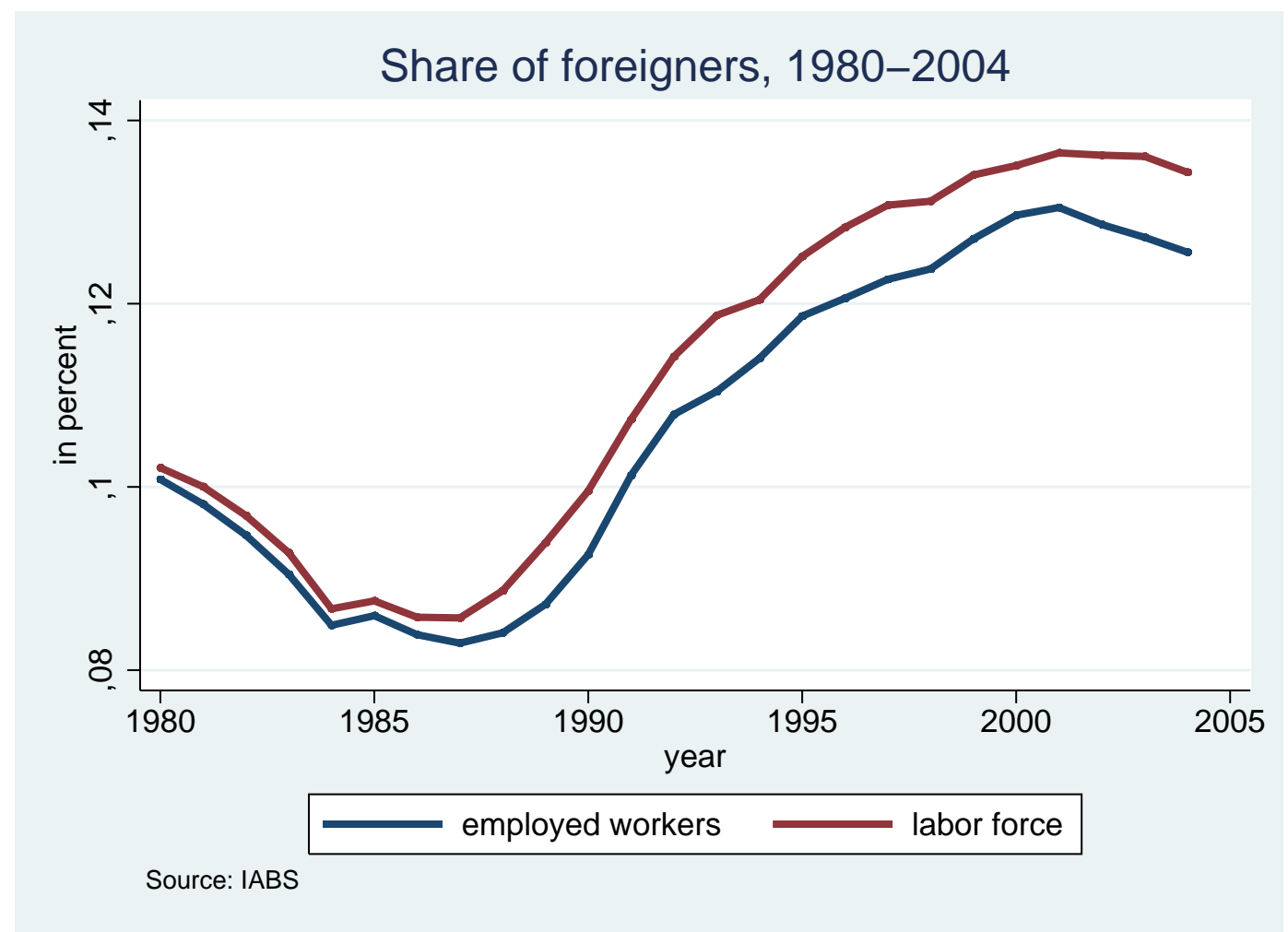

Figure 2: Share of foreign labor force and workers

Figure 2 displays the share of foreigners - including ethnic Germans - in the labor force and the share of foreigners among the employed workforce. During the 1980s, we observe a sharp decline, which is a consequence of tightening migration restrictions after the first and second oil price shock in Germany. The sharp increase in the foreigner share during the 1990s is a result of the fall of the Berlin wall and the civil wars in the former Yugoslavia, which triggered large migration flows to Germany. Note that the ethnic Germans who contributed substantially to the increasing labor supply in the 1990s are treated here as foreigners. Since the beginning of the 2000s the foreigner share is stagnating as a consequence of the slowdown of economic growth and tightening of immigration conditions. Moreover, 
foreigners tend to be more than proportionally affected by unemployment, such that their share in the employed workforce declined relative to their share in the labor force during the 1990s (Figure 2).

The foreign labor force increased dramatically during the period 1984 to 1993 as a consequence of the fall of the Berlin wall and the transition in Central and Eastern Europe. We therefore simulate the effects of this particular labor supply shock separately.

Table A1 presents the share of the foreign workforce by education and experience classes. The foreign workforce is heavily concentrated in the group of no vocational training. The foreigner share is moreover increasing in this low-skilled segment of the labor market from 31 percent in 1980 to 48 percent in 2004. In the other educational groups, the foreigner share varies between 5 percent and 9 percent. In the high-skilled segment of the labor market, the foreigner share fell from 7.5 percent in 1980 to 5.5 percent in the 1990s and recovered slightly later, achieving a share of 6.5 percent in the early 2000s. Altogether, the foreign workforce is more than proportionally represented in the low-skilled segment of the labor market.

Tables A2 and A3 display the wage levels for natives and foreign workers by education and experience groups. We report gross wages on a daily basis. A consistent consumer price index for the observation period is not available. We therefore employed the GDP deflator for the deflation of wages.

Wage levels increase with education levels and with experience in all education groups. The wage levels of foreign workers are in all education groups below those of their counterparts in the native labor force. While these differences are fairly small in the education groups of no vocational degree, they amount to about ten percent in the other education groups (see Tables A2 and A3).

\section{Estimation}

\subsection{Wage curves}

A large empirical literature estimates wage curves using the variance of wages and unemployment rates across regions and branches (see Blanchflower and Oswald, 1994a, 1995; Card, 1995). Based on this approach Baltagi and Blien (1998) have estimated the elasticity of the wage curve at about -0.07 for Western Germany, which matches the average elasticity of about -0.08 found in several OECD countries (see Nijkamp and Poot, 2005). However, in a recent study for Germany, Baltagi, Blien, and Wolf (2007) estimate the longrun elasticity between the wage and the unemployment rate at between -0.02 
and -0.03 employing a dynamic fixed effects model.

Based on the model outlined in Section 3, we deviate here from the standard approach by using the variance of wages and unemployment rates over time and across education and experience groups for the identification of the wage curve instead of the variance across regions. Note that our dataset contains 25 time-series observations that can be used for identification. Moreover, we specify the model in dynamic form following Blanchard and Katz (1997), Blanchflower and Oswald (2005) and Bell, Nickell, and Quintini (2002) for the US and Baltagi, Blien, and Wolf (2007) for Germany. This allows to disentangle the short and long-run wage and employment effects of migration if labor markets do not respond instantaneously to labor supply shocks.

More specifically, we estimate the elasticity of the wage with respect to the unemployment rate by experience and education groups as

$$
\ln w_{i j t}=\beta_{i j} \ln w_{i j, t-1}+\eta_{i j} \ln u_{i j t}+\gamma_{i j} \tau_{i j t}+e_{i j t},
$$

where $\eta$ denotes the elasticity between the wage and the unemployment rate and $\tau$ a deterministic time trend. We consider a linear and a squared trend here. The error term $e_{i j t}$ is specified as a one-way error component model with fixed effects for each education-experience group. Since unemployment might be endogenous, we follow Blanchflower and Oswald (2005) and Baltagi, Blien, and Wolf (2007) and instrument the unemployment rate with the first, second, and third lag of the unemployment rate.

The model is estimated separately for each education and experience cell. In each regression we have pooled two experience groups together in order to achieve more stable results. We have not distinguished between natives and foreigners, assuming that the wage-setting mechanism provides equal wages in each education-experience cell.

Table 2 about here

The estimation results are displayed in Table 2. We have in all regressions the expected negative sign for the coefficient on the unemployment rate. The autoregressive parameter on the lagged wage is well below 1, supporting a wage curve rather than a Phillips curve. Moreover, in most regressions the short-run and the long-run elasticities between the wage and the unemployment rate are highly significant. We obtain only insignificant results in the group of workers with a high school degree and university degree and the 
most extensive work experience, suggesting that the responsiveness of wages to the unemployment rate is close to zero in this segment of the labor market.

The first regressions provide estimates of the wage curve for all groups and for each education group separately. In the regression where all educationexperience groups are pooled, we find a short-run elasticity of about -0.03 and a long-run elasticity of about -0.12 . This is slightly higher than the average elasticity of -0.08 found by the regional-level wage curve literature in other OECD countries, but much higher than the elasticity of -0.03 estimated by Baltagi, Blien, and Wolf (2007) at the regional level in Germany.

Interestingly enough, the long-run elasticities are high at both ends of the skill spectrum: in the labor market segment without a vocational degree we find a long-run elasticity of about -0.14, and in the high-skilled segment of individuals with a university degree a long-run elasticity of -0.16 . The elasticity is particularly low in the segment with a vocational training degree, i.e., the labor market segment with a high share of unionized workers.

Even more intriguing is our finding of extremely high elasticities in segments with low work experience. Here we obtain long-run elasticities of between -0.24 and -0.63 . For workers without a vocational degree the elasticities are particularly high. They decline monotonously with increasing work experience in all cells of our sample and are particularly low in the labor segment with work experience of more than 30 years.

The fixed effects specifications reported in Table 2 are subject to the Nickell (1981) bias of order $1 / T . T=23$ in our sample. Monte Carlo simulations suggest that the coefficients for the unemployment rate are slightly overstated in samples of this time dimension. We have also employed the Arellano and Bond (1991) GMM estimator for obtaining unbiased and consistent results. The GMM estimates yield slightly lower results than the standard fixed effects model, but are generally in line with the previous findings (see Table A4). The overall elasticity is, at -0.8 , lower than our findings, but the elasticities for the individual education groups are comparable with the IV-estimation results. Since the Sargan test statistics indicate that the GMM model suffers from overidentification, we use the standard IV-fixed effects estimation results for the simulation of the migration effects.

Altogether, our empirical findings support the hypothesis that wages respond to an increase in the unemployment rate, and, hence, to labor supply shocks.

\subsection{Capital adjustment}

The impact of migration on aggregate wages depends largely on the adjustment of the capital stock. The Kaldor (1961) stylized facts on economic 
growth suggest that the capital-output ratio remains constant over time, indicating that capital stocks adjust to changes in labor supply.

The OECD data on capital stocks indeed demonstrate that the capitaloutput ratio has increased only slightly from about 3.0 to 3.15 in Germany during the four decades since 1960. Moreover, the fluctuations around the long-run ratio of 3.1 are relatively low. Even German reunification did not result in a visible break in the time series.

We employ two specifications for analyzing the impact of the labor supply on the capital-output ratio. First, to analyze whether a change in the labor supply affects the steady-state level of the capital-output ratio, we estimate

$$
\ln \kappa_{t}=\beta_{0}+\beta_{1} \ln \kappa_{t-1}+\beta_{2} \ln N_{t}+\beta_{3} \tau_{t}+\varepsilon_{t},
$$

and, second, to analyze the short-term deviation of $\kappa$ from its long-term growth path

$$
\ln \kappa_{t}=\gamma_{0}+\gamma_{1} \ln \kappa_{t-1}+\gamma_{2} \Delta \ln N_{t}+\gamma_{3} \tau_{t}+\epsilon_{t},
$$

where $\kappa_{t}$ denotes, as above, the capital-output ratio, $N_{t}$ the total labor force, $\tau_{t}$ a deterministic time trend which captures the balanced growth path trajectory of $\ln \left(\kappa_{t}\right)$, and $\varepsilon_{t}$ and $\epsilon_{t}$, disturbances which are assumed to be white noise. We have moreover added a dummy variable that controls for a possible structural break after German reunification.

Table 3 about here

The results are displayed in Table 3. The coefficient on $\ln \left(N_{t}\right)$ is positive and insignificant in the first equation, suggesting that the labor supply does not affect the capital-output ratio on the balanced growth path. In the second equation, the coefficient on the difference in the labor force is negative but not significant from zero.

Thus, we find no significant evidence that a change in labor supply has a short-run impact on the capital-output ratio. In the simulations on the migration impact, we assume that the capital-output ratio remains constant in the long run, while we use the small negative coefficient on the first difference of the log labor force from the second regression for the simulations of the short-run impact. 


\subsection{Elasticity of substitution between natives and for- eigners}

The model outlined in Section 3 relies on the assumption that firms hire workers until the marginal product of workers equals the wage rate. This allows us to identify the parameters of the production function analogously to Borjas (2003) and Ottaviano and Peri (2006) by the elasticities of relative labor demand.

Let us start with the identification of the elasticity of substitution between native and foreign workers. The relative demand of native and foreign workers of education $i$ and experience $j$ can be expressed as

$$
\ln \left(w_{i j h t} / w_{i j f t}\right)=\ln \left(\theta_{i j h} / \theta_{i j f}\right)-\frac{1}{\sigma_{i}} \ln \left(L_{i j h t} / L_{i j f t}\right) .
$$

For identifying the ratio $\theta_{i j h} / \theta_{i j f}$, we employ dummy variables for each education-experience cell. Conditional on these controls, we assume that changes in the relative employment of natives and foreigners in each education-experience cell are due to random shocks in the labor supply. We thus estimate the following regression to identify $\sigma_{i}$ :

$$
\ln \left(w_{i j h t} / w_{i j f t}\right)=D_{i j}-\frac{1}{\sigma_{i}} \ln \left(L_{i j h t} / L_{i j f t}\right)+\nu_{i j t},
$$

where the error term $\nu_{i j t}$ is a zero-mean random disturbance. In total we have $i \times j \times t=800$ observations. We estimate the equations by OLS and weighted OLS using total employment in each cell as a weight.

Table 4 about here

The results are reported in Table 4 . We ran the regressions separately for the total period 1980-2004 and for the subperiod 1984 to 1993, when Germany experienced a particular labor supply shock. In the total period, the coefficient for $\sigma_{i}$ is significantly different from zero in all regressions except for the groups of workers with a university degree, providing support for the hypothesis that native and foreign workers are imperfect substitutes in the first three education groups. However, the estimated coefficients for $1 / \sigma_{i}$ are, at between 0.05 and 0.07 , relatively small. This indicates that the elasticity of substitution between native and foreign workers lies between 15 and 20, which is relatively high. Moreover, the elasticity of substitution is not significantly different from zero in the weighted regression for high-skilled 
workers, suggesting that natives and foreigners are perfect substitutes in the high-skilled segment of the labor market. For the subperiod 1984-1993, we obtain very similar results, although the estimated coefficients are slightly larger and the standard errors slightly higher.

These results contrast with the relatively low elasticities found by Ottaviano and Peri (2006) for the US, but do not support the finding that natives and migrants are perfect substitutes (Aydemir and Borjas, 2007). The estimates by D'Amuri, Ottaviano, and Peri (2008) for Germany are, at between 0.04-0.06, very close to ours. Similarly, Felbermayr, Geis, and Kohler (2008) estimate this elasticity based on another dataset at between 0.07 and 0.1 .

For the further analysis, we use the education-specific estimates of the parameter $\sigma_{i}$ since the $F$-test rejects the null hypothesis that the coefficient is equal for all $\sigma_{i}$.

\subsection{Elasticity of substitution between experience groups}

In the next step we estimate the elasticity of substitution between experience groups. We first calculate the productivity weighted labor composite $L_{i j t}$. The estimates for the productivity parameters of native and foreign workers can be derived from the estimated fixed effects as

$$
\hat{\theta}_{i j h}=\frac{\exp \left(\hat{D}_{i j}\right)}{1+\exp \left(\hat{D}_{i j}\right)}, \quad \hat{\theta}_{i j f}=\frac{1}{1+\exp \left(\hat{D}_{i j}\right)},
$$

where we have used the restriction that the productivity terms add up to one. We can then employ the estimates for $\hat{\theta}_{i j h}$ and $\hat{\theta}_{i j f}$ and of $\hat{\sigma}_{i}$ to calculate $\hat{L}_{i j t}$ as

$$
\hat{L}_{i j t}=\left[\hat{\theta}_{i j h} L_{i j h t}^{\left(\hat{\sigma}_{i}-1\right) / \hat{\sigma}_{i}}+\hat{\theta}_{i j f} L_{i j f t}^{\left(\hat{\sigma}_{i}-1\right) / \hat{\sigma}_{i}}\right]^{\hat{\sigma}_{i} /\left(\hat{\sigma}_{i}-1\right)} .
$$

From the production function we receive the wage for the labor composite $L_{i j t}$

$\ln w_{i j t}=\ln \left(\alpha A_{t}^{1 / \alpha} \kappa_{t}^{\frac{1-\alpha}{\alpha}}\right)+\frac{1}{\delta} \ln L_{t}+\ln \theta_{i t}-\left(\frac{1}{\delta}-\frac{1}{\rho}\right) \ln L_{i t}+\ln \theta_{i j}-\frac{1}{\rho} \ln L_{i j t}$.

We identify the elasticity of substitution $\rho$ by estimating

$$
\ln w_{i j t}=D_{t}+D_{i t}+D_{i j}-\frac{1}{\rho} \ln \hat{L}_{i j t}+v_{i j t},
$$

where the time-specific fixed effects $D_{t}$ control for the variance of 
$\ln \left(\alpha A_{t}^{1 / \alpha} \kappa_{t}^{\frac{1-\alpha}{\alpha}}\right)+\frac{1}{\delta} \ln \left(L_{t}\right)$, and the time by education-specific fixed effects $D_{i t}$ for the variation in $\ln \left(\theta_{i t}\right)+\left(\frac{1}{\delta}-\frac{1}{\rho}\right) \ln \left(L_{i t}\right)$ and the education-experience group fixed effects $D_{i j}$ for the productivity term $\ln \theta_{i j}$, which is assumed to be constant over time. This allows us to consistently estimate the parameter $-\frac{1}{\rho}$ by 2 SLS, where we use the number of native workers in each experienceeducation group as an instrument.

Table 5 about here

We find an elasticity of substitution of about 30 in the regressions that refer to the total period, which is substantially higher than the elasticity of substitution of between 4 and 5, which Borjas (2003), Card and Lemieux (2001) and Ottaviano and Peri (2006) obtain in their studies for the US. ${ }^{7}$ Interestingly enough, Felbermayr, Geis, and Kohler (2008) obtain similar elasticities for Germany as we do, although they employ another dataset for their analysis. As a robustness check we have also assumed an infinite elasticity of substitution between native and foreign workers in the calculation of $L_{i j t}$, which yields however very similar results. In the subperiod 1984 1993 we estimate a coefficient 0.064, which corresponds to an elasticity of substitution in the vicinity of 16 (see Table 5).

\subsection{Elasticity of substitution between education groups}

Analogously to the previous section we use the estimated fixed effects $\hat{D}_{i j}$ to calculate the efficiency parameters $\theta_{i j}$ as

$$
\hat{\theta}_{i j}=\frac{\exp \left(\hat{D}_{i j}\right)}{\sum_{j} \exp \left(\hat{D}_{i j}\right)},
$$

which in turn allows to compute the estimated value of the productivity weighted labor composite $L_{i t}$ as

$$
\hat{L}_{i t}=\left[\sum_{j=1}^{8} \hat{\theta}_{i j} \hat{L}_{i j t}^{(\hat{\rho}-1) / \hat{\rho}_{i}}\right]^{\hat{\rho} /(\hat{\rho}-1)} .
$$

\footnotetext{
${ }^{7}$ In their recent study on Germany, D'Amuri, Ottaviano, and Peri (2008) do not provide estimates for the elasticity of substitution across experience and education groups but use the US estimates.
} 
From the production function we have

$$
\ln w_{i t}=\ln \left(\alpha A_{t}^{1 / \alpha} \kappa_{t}^{\frac{1-\alpha}{\alpha}}\right)+\frac{1}{\delta} \ln L_{t}+\ln \theta_{i t}-\frac{1}{\delta} \ln L_{i t},
$$

which enables us to identify the parameter $\frac{1}{\delta}$ as

$$
\ln w_{i t}=D_{t}+D_{i}+\lambda_{i} \tau_{i}-\frac{1}{\delta} \ln \hat{L}_{i t}+\vartheta_{i t}
$$

The time-specific fixed effects $D_{t}$ control for the variance in $\ln \left(\alpha A_{t}^{1 / \alpha} \kappa_{t}^{\frac{1-\alpha}{\alpha}}\right)+$ $\frac{1}{\delta} \ln \left(L_{t}\right)$ and the education-specific fixed effects $D_{i}$ and the education-specific deterministic time trend $\tau_{i}$ for the variance in the skill-specific efficiency parameter $\theta_{i t}$. $\vartheta_{i t}$ is assumed to be a zero-mean random disturbance. To estimate the parameter $-\frac{1}{\delta}$ consistently, we again employ the 2SLS estimator and use the number of foreign workers within each education group as an instrument for $\ln \hat{L}_{i t}$.

Table 6 about here

We receive for $1 / \delta$ an estimated parameter of about 0.15 in the total sample period, which corresponds to an elasticity of substitution between education groups of 6.5 (see Table 6). This elasticity is larger than the elasticities found in US studies (e.g. Katz and Murphy, 1992; Ottaviano and Peri, 2006), but again matches the findings by Felbermayr, Geis, and Kohler (2008) for Germany. As a robustness check we apply the assumption that the elasticity $\rho$ tends to infinity for the calculation of $L_{t}$, which yields a similar elasticity of substitution. In the subperiod 1984-1993 we find an elasticity of substitution of about 3, which is similar to the findings in the US literature (Table 6).

Finally, the parameter $\alpha$ has been calculated from the labor share in national income which yields an average value of 0.67 .

\section{Simulation results}

We now use the estimated parameter values for the simulation of the impact of migration on (un-)employment and wages. In each scenario, we distinguish between the short-run and the long-run effects of migration. For the simulation of the short-run effects we employ the short-run coefficients for the 
elasticity $\hat{\eta}_{i j}$ from the wage curve estimates and the (small) negative effect of an increase in the labor force on the capital-output ratio. The long-run effects are calculated by using the long-run elasticities of the wage curve and by assuming that the capital-output ratio remains constant.

We simulate the following scenarios here. First, we simulate the effects of a one percent increase of the labor force through immigration using the average distribution of foreigners across the education-experience cells of the labor market. This implies that the overwhelming majority of the increase takes place in the education group of those with no vocational training, while the increase in the other education groups is modest. This scenario provides an indication as to the marginal effects of immigration at the given structure of the workforce.

In order to analyze the sensitivity of our findings, we simulate a counterfactual scenario under the assumption that labor markets are perfectly flexible, i.e., that $\eta_{i j} \rightarrow-\infty \forall i j$. This scenario allows us to compare our findings with those reported in the standard literature (e.g. Borjas, 2003; Ottaviano and Peri, 2006).

In the next step we simulate the wage and employment effects of immigration for the total sample period, i.e., from 1980 to 2004. We consider the actual changes in each cell of the labor market here. Finally, we simulate the labor market effects of the labor supply shock during the ten-year period 1984 - 1993, which covers the fall of the Berlin wall.

The employment and wage effects are calculated for native and foreign workers for each education-experience group. For the aggregation, we weighted the wage changes by the income share in each cell, and the changes in the unemployment rate by the share in the labor force in each cell. In the tables, we report the average effects for the total labor force, the native labor force, and the foreign labor force by education levels.

Table 7 about here

A one percent immigration of workers with the same education and experience characteristics as the existing foreign workforce reduces average wages by less than 0.1 percent and increases the average unemployment rate by less than 0.1 percent in the short run, while the long-run impact is neutral. Particularly negatively affected are workers with no vocational training degree and a high school degree, where the shares of the foreign workforce are relatively high. The native workforce benefits slightly on average both from increasing wages and from declining unemployment. However, native workers lose slightly in the segments with no vocational degree and a high school 
degree. In contrast, wages of foreign workers tend to decline by about 0.6 percent, while the unemployment rate increases by 0.3 percentage points in the short run and 0.1 percentage points in the long run (Table 7).

Table 8 about here

In Table 8 we have simulated the potential wage impact of one percent immigration under the counterfactual assumption of perfect labor markets. We find slightly higher wage effects than in the previous scenario, but the overall pattern is the same: average wages of the total labor force decrease slightly in the short run while immigration is neutral in the long run. While wages of native workers tend to increase slightly, those of foreign workers tend to decline by 0.6 percent in the short run. The pattern of our findings is similar to that in the findings of Ottaviano and Peri (2006) for the US, but both the wage losses of the foreign workforce and the wage gains of the native workforce are much smaller in our case since the elasticity of substitution between native and foreign workers is higher in Germany.

The real labor supply shock during the 1980 - 2004 period changed the structure of the foreign workforce: while the number of workers without a vocational degree declined substantially, the labor supply of foreigners increased substantially in the other education groups of the labor market. Particularly affected was the rather small group with a high school degree, but the groups with a vocational degree and a university degree faced a substantial labor supply shock as well during this period. Average wages declined by about 0.1 percent in the short run and remained stable in the long run. Interestingly enough, the unemployment rate decreased in the short run, but increased slightly in the long run. This counterintuitive finding can be traced back to the fact that the change in the composition of the foreign workforce reduced the unemployment rate in the labor market segment without a vocational degree. The positive employment effects there overcompensated for the increasing unemployment in the other segments of the labor market. However, in the long run, wages adjust such that the employment gains in the lowskilled segment of the labor market are mitigated.

The wage impact of migration on the native labor force is almost neutral, but natives tend to benefit by a slightly decreasing unemployment rate in the short run. The foreign labor force experiences a substantial wage loss of about 1.2 percent in the short run and 1 percent in the long run. The unemployment rate declines in the short run by about 0.3 percentage points, but increases in the long-run by 0.4 percentage points. Note that the 
unemployment rate of foreign workers without a vocational degree declines substantially by 4.1 percentage points in the short run, but that this decline shrinks to 0.9 percentage points when wages have adjusted in the long run. Altogether, wages of foreign workers are adversely affected by the increasing labor supply, while the impact on unemployment is ambiguous due to the change in the skill composition of the foreign workforce (Table 8).

Table 9 about here

Finally, we simulated the effects of the immigration shock during the 19841993 period, when the foreign workforce increases by about 40 percent. This labor supply shock means that average wages decline by almost 0.2 percent, while the average unemployment rate increases by 0.4 percentage points in the short run. Nevertheless, the wage impact of migration is neutral in the long run, while the unemployment rate increases by less than 0.2 percentage points. Interestingly enough, the native workforce tends to gain both in terms of higher wages and lower unemployment. In the long run, native wages increase by more than 0.2 percent, while the unemployment rate declines by more than 0.1 percentage points. In contrast, wages of the foreign labor force decline by almost 3 per cent. The unemployment rate of the foreign workforce increases by 2.6 percentage points in the short run and by 1.4 percentage points in the long run. Particularly affected are the groups with a high school degree and a vocational degree (Table 9 ).

\section{Conclusions}

In this paper we presented a general equilibrium framework that allows us to analyze the wage and employment effects of migration simultaneously. We modeled wage rigidities in form of a wage curve, which assumes that wages respond imperfectly to an increase in the unemployment rate. In the empirical application of the model we found that the elasticities of the wage curve differ widely for the different segments of the labor market. While the elasticity of the wage with respect to the unemployment rate is relatively high in the segments of the labor market with a university degree and limited work experience, it is particularly low in the labor market segment with a vocational degree and extensive work experience.

At the given structure of the foreign workforce, migration reduces average wages and increases unemployment of the total workforce slightly, while it is neutral in the long run. More interesting are the structural effects: while 
native workers tend to benefit, the foreign workforce tends to suffer from lower wages and increasing unemployment, at least in the short run.

The simulation of the actual immigration impact demonstrates that the shift in the skill structure of the foreign labor force can reduce the total unemployment rate if wage rigidities exist. A decreasing labor supply in the low-skilled segment of the labor market and an increasing labor supply in the segments with a higher skill level can reduce the overall unemployment rate if wages do not completely adjust to labor demand changes. Indeed, we find that immigration during the 1980 - 2004 period has reduced total unemployment in the short run, while this effect disappears in the long run when wages have adjusted.

Moreover, our empirical analysis has produced further intriguing results. Compared to the findings from the US studies, the elasticity of substitution between natives and foreigners is relatively high in Germany. This implies that the labor market effects of migration are relatively similar for natives and migrants within the same education and experience cells. However, native and foreign workers remain imperfect substitutes.

The elasticity of substitution across education groups is about twice as high in Germany as in the US, and the elasticity of substitution across experience groups is substantially larger. As a consequence, the effects of migration are more evenly distributed across the education and experience groups of the labor market in Germany than in the US.

Finally, we found strong evidence that capital stocks adjust to labor supply shocks. We found no negative relationship between labor supply and the capital-output ratio in the long run, and only small and insignificant effects for short-term supply shocks. This supports one of the famous stylized facts on economic growth by Nicholas Kaldor (1961) and the evidence that Ottaviano and Peri (2006) found for the US. This again has important implications for the wage effects of migration: at least in the long run, an increasing labor supply through migration does not reduce the average wage level in the economy.

\section{References}

Arellano, M., And S. Bond (1991): "Some Tests of Specification for Panel Data: Monte Carlo Evidence and an Application to Employment Equations," Review of Economic Studies, 58, 277-97.

Aydemir, A., And G. J. BorJas (2007): "Cross-Country Variation in 
the Impact of International Migration: Canada, Mexico and the United States," Journal of the European Economic Association, 5(4), 663-708.

Baltagi, B. H., and U. Blien (1998): "The German wage curve: evidence from the IAB employment sample," Economic Letters, 61, 135 - 142.

Baltagi, B. H., U. Blien, and K. Wolf (2007): "Philipps Curve or Wage Curve: Evidence from West Germany: 1980-2004," IAB Discussion Paper 14/2007.

Bauer, T., and K. F. Zimmermann (1997): "Unemployment and wages of ethnic Germans," Quarterly Review of Economics and Finance, 37, 361 -377 .

Bell, B., S. Nickell, And G. Quintini (2002): "Wage equations, wage curves and all that," Labour Economics, 9, 341-360.

Bentolila, S., J. J. Dolado, and J. F. Jimeno (2007): "Does Immigration Affect the Philipps Curve? Some Evidence for Spain," Kiel Working Papers 1333, Kiel Institute for the World Economy (IfW), Kiel.

Blanchard, O. J. (2003): Macroeconomics, 3rd Edition. London.

Blanchard, O. J., and L. F. Katz (1997): "What we know and do not know about the natural rate of unemployment," Journal of Economic Perspectives, 11(1), 51-72.

Blanchflower, D. D., And A. J. Oswald (1994a): The wage curve. Cambridge MA.

- (1995): "An introduction to the wage curve," Journal of Economic Perspectives, 9, 153-165.

(2005): "The wage curve reloaded," NBER Working Paper 11338.

Boeri, T., And H. BrüCKer (2005): "Why are Europeans so tough on migrants?," Economic Policy, 44, 631-703.

Bonin, H. (2005): "Wage and employment effects of immigration to Germany: evidence from a skill group approach," IZA Discussion Paper 1875.

Bonin, H., B. Raffelhüschen, and J. Walliser (2000): "Can Immigration Alleviate the Demographic Burden," FinanzArchiv, 57, 1-21. 
BorJas, G. J. (2003): "The Labor Demand Curve is Downward Sloping: Reexamining the Impact of Immigration on the Labor Market," CXVIII(4), 1335-1374.

Borjas, G. J., R. Freemann, and L. Katz (1997): "How Much do Immigration and Trade Affect Labor Market Outcomes?," Brookings Papers on Economic Activity, (1), 1-90.

Borjas, G. J., J. Grogger, and G. H. Hanson (2006): "Immigration and African-American Employment Opportunities: The Response of Wages, Employment, and Incaceration to Labor Supply Shocks," NBER Working Paper 12518.

BrüCker, H., And P. Trübswetter (2007): "Do the Best Go West? An Analysis of the Self-Selection of Employed East-West Migrants in Germany," Empirica, 34, 371 - 395.

Bundesamt, S. (2006): "Informationen zur Ost-West Wanderung," Statistisches Bundesamt, Wiesbaden.

Burda, M. C., and J. Hunt (2001): "From German Reunification to Economic Integration: Productivity and the Labor Market in Eastern Germany," Brooking Papers of Economic Activity, 2:2001, 1-91.

Büttner, T., And S. RÄssler (2007): "Imputation," Mimeo, IAB, Nürnberg.

CARD, D. (1990): "The Impact of the Mariel Boatlift on the Miami Labor Market," Industrial and Labor Relations Review, 43, 245-257.

(1995): "The wage curve: a review," Journal of Economic Literature, 33, 785-799.

(2001): "Immigrant Inflows, Native Outflows, and the Local Labor Market Impacts of Higher Immigration," Journal of Labor Economics, 19, $22-64$.

Card, D., and T. Lemieux (2001): "Can Falling Supply Explain the Rising Return to College for Younger Men? A Cohort Based Analysis," Quarterly Journal of Economics, CXVI, 705-746.

Carrington, W. J., and P. DeLima (1996): "The Impact of the 1970s Repatriates from Africa on the Portuguese Labour Market," Industrial and Labor Relations Review, 49, 330-346. 
D'Amuri, F., G. Ottaniano, and G. Peri (2008): "The Labor Market Impact of Immigration in Western Germany in the 1990's," NBER Working Paper No. 13851, March.

DeNew, J., And K. F. Zimmermann (1994): "Native Wage Impacts of Foreign Labor: A Random Effects Panel Analysis," Journal of Population Economics, 7, 177-192.

Felbermayr, G., W. Geis, and W. Kohler (2008): "Absorbing German Immigration: Wages and Employment," Mimeo, University of Tübingen.

Fitzenberger, B., A. Osikominu, and R. VÖlter (2005): "Imputation Rules to Improve the Education Variable in the IAB Employment Subsample," ZEW Discussion Paper No 05-10; Mannheim.

Freeman, R. (2006): "People Flows in Globalization," Journal of Economic Perspectives, 9(2), 23-44.

FriedberG, R. M., And J. Hunt (1995): "The Impact of Immigrants on Host Country Wages, Employment and Growth," Journal of Economic Perspectives, 9, 23-44.

Guichard, S., And J.-P. Laffargue (2000): "The wage curve: the lessons of an estimation over a panel of countries," CEPII, Document de travail no. 2000-21.

Haisken-DeNew, J., and K. F. Zimmermann (1995): "Wage and Mobility Effects of Trade and Migration," CEPR Discussion Paper, No. 1318.

Harris, J. R., And M. Todaro (1970): "Migration unemployment and development: a two sector analysis," American Economic Review, 60, 126 -142 .

Hatizius, J. (1994): "The Unemployment and Earnings Effect of German Immigration," Applied Economics Discussion Paper No. 165, Oxford Institute for Economics and Statistics.

Hunt, J. (1992): "The Impact of the 1962 Repatriates from Algeria on the French Labor Market," Industrial and Labor Relations Review, 45, 556572.

(2006): "Staunching Emigration from East Germany: Age and the Determinants of Migration," Journal of the European Economic Association, 4(5), $1014-1037$. 
INADA, K.-I. (1963): "On a Two-Sector Model of Economic Growth: Comments and a Generalization," Review of Economic Studies, 30, 119-127.

JAEGER, D. (1996): "Skill Differences and the Effects of Immigrants on the Wages of Natives," Working Paper, U.S. Bureau of Labor and Statistics.

KALDOR, N. (1961): "Capital accumulation and economic growth," in The Theory of Capital, ed. by F. Lutz, and D. Hague. St. Martins, New York.

Katz, L., And K. Murphy (1992): "Change in Relative Wages 1963-1987: Supply and Demand Factors," Quarterly Journal of Economics, 107, 35 78.

LAyard, R., S. NiCKell, And R. JACKMAN (1991): Unemployment: Macroeconomic Performance and the Labour Market. Oxford University Press, Oxford.

Layard, R., and S. J. Nickell (1986): "Unemployment in Brtain," Economica, 53, Supplement 1986, S121-S169.

Levine, P. (1999): "The welfare economics of migration control," Journal of Population Economics, 12, 23-43.

LindBeCK, A. (1993): Unemployment and Macroeconomics. MIT Press, Cambridge, MA.

Longhi, S., P. NiJkamp, and J. Poot (2005): "A Meta-Analytic Assessment of the Effects of Immigration on Wages," Journal of Economic Surveys, 19(3), 451-477.

(2006): "The Impact of Immigration on the Employment of Natives in Regional Labour Markets: A Meta-Analysis," IZA Discussion Paper 2044, Bonn.

Mühleisen, M., and K. F. Zimmermann (1994): "A Panel Analysis of Job Changes and Unemployment," European Economic Review, 38, 793801.

Nickell, S. (1981): "Biases in Dynamic Models with Fixed Effects," Econometrica, 49(6), 1417 - 1426.

NiJkamp, P., And J. Poot (2005): "The last word on the wage curve? A meta-analytic assessment," Journal of Economic Surveys, 19, 421-450. 
Ottaviano, G., and G. Peri (2005a): "Cities and Cultures," Journal of Urban Economics, 58(2), $304-307$.

(2005b): "Rethinking the Gains from Immigration: Theory and Evidence from the US," NBER Working Paper 11672.

(2006): "Rethinking the Effects of Immigration on Wages," NBER Working Paper 12497.

Phillips, A. W. (1958): "The relation between unemployment and the rate of change of money wage rates in the United Kingdom, 1861-1957," Economica, 25(100), 283-299.

Pischke, J. S., And J. Velling (1997): "Employment effects of immigration to Germany: an analysis based on local labor markets," Review of Economics and Statistics, 79, 594-604.

Sargan, J. D. (1964): "Wages and Prices in the United Kingdom: A Study in Econometric Methodology," in Econometrics and quantitative economics, ed. by D. Hendry, and K. Wallis. Basil Blackwell, New York.

Shapiro, C., And J. E. Stiglitz (1984): "Equilibrium unemployment as a worker discipline device," American Economic Review, 74, 433 - 444.

Wagner, T., And E. J. Jahn (2004): Neue Arbeitsmarkttheorien, 2nd edition. Lucius and Lucius, Stuttgart.

Wong, K.-Y. (1995): International Trade in Goods and Factor Mobility. MIT-Press.

World BAnk (2007): World Development Indicators. World Bank, Washington, DC.

Zimmermann, K. F. (1999): "Ethnic German Migration since 1989 - Results and Perspectives," IZA Discussion Paper 50. 


\section{A Appendix}

The general solution for the marginal employment response is given by equation (4), i.e. by

$$
\frac{d \mathbf{L}}{d M}=\left(\frac{\partial \mathbf{w}}{\partial \mathbf{L}}-\frac{\partial \phi}{\partial \mathbf{u}} \frac{\partial \mathbf{u}}{\partial \mathbf{L}}\right)^{-1} \times\left(\frac{\partial \phi}{\partial \mathbf{u}} \frac{\partial \mathbf{u}}{\partial \mathbf{N}} \frac{d \mathbf{N}}{d M}-\frac{\partial \mathbf{w}}{\partial \kappa} \frac{d \kappa}{d M}\right)
$$

where we have used the definition of $\kappa$. Using the nested structure of the production function we can write

$$
\begin{aligned}
\mathbf{w} & =\left[w_{111}, w_{112}, w_{121}, \ldots, w_{211}, \ldots, w_{i j k}, \ldots, w_{482}\right], \\
\mathbf{L} & =\left[L_{111}, L_{112}, L_{121}, \ldots, L_{211}, \ldots, L_{i j k}, \ldots, L_{482}\right], \\
\mathbf{N} & =\left[N_{111}, N_{112}, N_{121}, \ldots, N_{211}, \ldots, N_{i j k}, \ldots N_{482}\right], \\
\mathbf{u} & =\left[u_{111}, u_{112}, u_{121}, \ldots, u_{211}, \ldots, u_{i j k}, \ldots, u_{482}\right], \\
\phi & =\left[\phi_{111}, \phi_{112}, \phi_{121}, \ldots, \phi_{211}, \ldots \phi_{i j k}, \ldots, \phi_{482}\right] .
\end{aligned}
$$

The term $\frac{\partial \mathbf{w}}{\partial \mathbf{L}}$ is the $64 \times 64$ matrix

$$
\frac{\partial \mathbf{W}}{\partial \mathbf{L}}=\left[\begin{array}{ccccc}
\frac{\partial w_{111}}{\partial L_{111}} & \cdots & \frac{\partial w_{111}}{\partial L_{i j k}} & \cdots & \frac{\partial w_{111}}{\partial L_{482}} \\
\vdots & & \vdots & & \vdots \\
\frac{\partial w_{i j k}}{\partial L_{111}} & \cdots & \frac{\partial w_{i j k}}{\partial L_{i j k}} & \cdots & \frac{\partial w_{i j k}}{\partial L_{482}} \\
\vdots & & \vdots & & \vdots \\
\frac{\partial w_{482}}{\partial L_{111}} & \cdots & \frac{\partial w_{482}}{\partial L_{i j k}} & \cdots & \frac{\partial w_{482}}{\partial L_{482}}
\end{array}\right] .
$$

Note that we have from the nested structure of the production function four types of partial derivatives of any wage $w_{i j k t}$ :

$$
\begin{aligned}
\frac{\partial w_{i j k}}{\partial L_{i j k}} & =\frac{w_{i j k}}{L_{i j k}}\left[s_{i j k}\left\{\frac{1}{\delta}-\frac{1}{s_{i}}\left(\frac{1}{\delta}-\frac{1}{\rho}\right)-\frac{1}{s_{i j}}\left(\frac{1}{\rho}-\frac{1}{\sigma_{i}}\right)\right\}-\frac{1}{\sigma_{i}}\right], \\
\frac{\partial w_{i j k}}{\partial L_{i j k^{\prime}}} & =\frac{w_{i j k}}{L_{i j k^{\prime}}}\left[s_{i j k^{\prime}}\left\{\frac{1}{\delta}-\frac{1}{s_{i}}\left(\frac{1}{\delta}-\frac{1}{\rho}\right)-\frac{1}{s_{i j}}\left(\frac{1}{\rho}-\frac{1}{\sigma_{i}}\right)\right\}\right], \\
\frac{\partial w_{i j k}}{\partial L_{i j^{\prime} m}} & =\frac{w_{i j k}}{L_{i j^{\prime} m}}\left[s_{i j^{\prime} m}\left\{\frac{1}{\delta}-\frac{1}{s_{i}}\left(\frac{1}{\delta}-\frac{1}{\rho}\right)\right\}\right], \\
\frac{\partial w_{i j k}}{\partial L_{i^{\prime} n m}} & =\frac{w_{i j k}}{L_{i^{\prime} n m}}\left[s_{i^{\prime} n m} \frac{1}{\delta}\right],
\end{aligned}
$$

where $\frac{\partial w_{i j k}}{\partial L_{i j k}}$ is the partial derivative of the wage with respect to labor in the 
same education, experience and nationality cell of the labor market, $\frac{\partial w_{i j k}}{\partial L_{i j k^{\prime}}}$ the partial derivative of the wage with respect to labor of the same education and experience, but different nationality, $\frac{\partial w_{i j k}}{\partial L_{i j^{\prime} m}}$ the partial derivative of the wage with respect to labor of the same education, but different experience, $\frac{\partial w_{i j k}}{\partial L_{i^{\prime} n m}}$ the partial derivative of the wage with respect to labor of different education, and $s_{i j k}, s_{i j}, s_{i}$, etc. denote the share of wages paid to workers in the respective cells of the labor market in the total wage bill.

The term $\frac{\partial \mathbf{f}}{\partial \mathbf{u}} \frac{\partial \mathbf{u}}{\partial \mathbf{L}}$ is given by the $64 \times 64$ matrix

$$
\frac{\partial \mathbf{f}}{\partial \mathbf{u}} \frac{\partial \mathbf{u}}{\partial \mathbf{L}}=\left[\begin{array}{ccccc}
\frac{\partial f_{111}}{\partial u_{111}} \frac{\partial u_{111}}{\partial L_{111}} & \cdots & 0 & \cdots & 0 \\
\vdots & \ddots & & & \vdots \\
0 & & \frac{\partial f_{i j k}}{\partial u_{i j k}} \frac{\partial u_{i j k}}{\partial L_{i j k}} & & 0 \\
\vdots & & & \ddots & \vdots \\
0 & \cdots & 0 & \cdots & \frac{\partial f_{482}}{\partial u_{482}} \frac{\partial u_{482}}{\partial L_{482}}
\end{array}\right]
$$

Finally, we can write the term $\frac{\partial \mathbf{f}}{\partial \mathbf{u}} \frac{\partial \mathbf{u}}{\partial \mathbf{N}} \frac{d \mathbf{N}}{d M}$ as the $1 \times 64$ vector

$$
\frac{\partial \mathbf{f}}{\partial \mathbf{u}} \frac{\partial \mathbf{u}}{\partial \mathbf{n}} \frac{d \mathbf{N}}{d M}=\left[\begin{array}{c}
\frac{\partial f_{111}}{\partial u_{111}} \frac{\partial u_{111}}{\partial N_{111}} \frac{d N_{111}}{d M} \\
\vdots \\
\frac{\partial f_{i j k}}{\partial u_{i j k}} \frac{\partial u_{i j k}}{\partial N_{i j k}} \frac{d N_{i j k}}{d M} \\
\vdots \\
\frac{\partial f_{482}}{\partial u_{482}} \frac{\partial u_{482}}{\partial N_{482}} \frac{d N_{482}}{d M}
\end{array}\right]
$$

and the term $\frac{\partial \mathbf{w}}{\partial \kappa} \frac{d \kappa}{d M}$ as the $1 \times 64$ vector

$$
\frac{\partial \mathbf{w}}{\partial \kappa} \frac{d \kappa}{d M}=\left[\begin{array}{c}
\frac{\partial w_{111}}{\partial \kappa} \frac{d \kappa}{d M} \\
\vdots \\
\frac{\partial w_{i j k}}{\partial \kappa} \frac{d \kappa}{d M} \\
\vdots \\
\frac{\partial w_{482}}{\partial \kappa} \frac{d \kappa}{d M}
\end{array}\right]=\left[\begin{array}{c}
\frac{1-\alpha}{\alpha} \frac{w_{111}}{\kappa} \frac{d \kappa}{d M} \\
\vdots \\
\frac{1-\alpha}{\alpha} \frac{w_{i j k}}{\kappa} \frac{d \kappa}{d M} \\
\vdots \\
\frac{1-\alpha}{\alpha} \frac{w_{482}}{\kappa} \frac{d \kappa}{d M}
\end{array}\right]
$$

Substituting (A.1) to (A.4) for the individual terms in equation (4) yields the explicit solution for the employment response which we have used for our simulation of the employment response to migration. 
Table 1: Description of dataset (Western Germany, 1980 - 2004)

\begin{tabular}{lrrrr}
\hline \hline & \multicolumn{1}{c}{$\mathbf{1 9 8 0} \mathbf{- 2 0 0 4}$} & \multicolumn{2}{c}{$\mathbf{1 9 8 4} \mathbf{- 1 9 9 3}$} \\
& observations & percent & observations & percent \\
& & & & \\
\hline & & & & \\
all spells & $11,770,638$ & 100.0 & $4,460,817$ & 100.0 \\
minus part time workers / trainees & $2,698,193$ & 22.9 & 825,012 & 18.5 \\
minus age (below 15 and above 60) & 163,940 & 1.4 & 56,239 & 1.3 \\
minus missing nationality & 1,044 & 0.0 & 216 & 0.0 \\
minus missing education & 176,876 & 1.5 & 66,763 & 1.5 \\
minus wages below social & & & & \\
security contribution threshold & 81,716 & 0.7 & 15,033 & 0.3 \\
total & $8,648,869$ & 73.5 & $3,497,554$ & 78.4 \\
& & & & \\
\hline \hline
\end{tabular}

Source: Authors' calculations based on the IABS. 
Table 2: The wage curve: IV-estimation results

\begin{tabular}{|c|c|c|c|c|c|c|c|c|c|c|}
\hline \multirow{3}{*}{$\begin{array}{l}\text { education } \\
\text { degree }\end{array}$} & \multicolumn{3}{|c|}{$\ln w_{i j, t-1}$} & \multicolumn{5}{|c|}{$\ln u_{i j t}$} & & \multirow[b]{3}{*}{$\mathrm{R}^{2}$} \\
\hline & \multirow[b]{2}{*}{ coeff. } & \multirow[b]{2}{*}{ se } & & \multicolumn{2}{|c|}{ short-run } & & \multicolumn{2}{|c|}{ long-run } & & \\
\hline & & & & coeff. & se & & coeff. & se & & \\
\hline \multicolumn{11}{|c|}{ all experience groups } \\
\hline all & 0.731 & $(0.023)$ & $* * *$ & -0.032 & $(0.005)$ & $* * *$ & -0.119 & $(0.019)$ & $* * *$ & 0.85 \\
\hline no vocational & 0.691 & $(0.051)$ & $* * *$ & -0.044 & $(0.006)$ & $* * *$ & -0.142 & $(0.031)$ & $* * *$ & 0.94 \\
\hline vocational & 0.523 & $(0.052)$ & $* * *$ & -0.047 & $(0.006)$ & $* * *$ & -0.098 & $(0.015)$ & $* * *$ & 0.96 \\
\hline high school & 0.466 & $(0.064)$ & $* * *$ & -0.067 & $(0.017)$ & $* * *$ & -0.125 & $(0.030)$ & $* * *$ & 0.83 \\
\hline university & 0.366 & $(0.064)$ & $* * *$ & -0.100 & $(0.017)$ & $* * *$ & -0.157 & $(0.023)$ & $* * *$ & 0.86 \\
\hline \multicolumn{11}{|c|}{ experience group 1 and 2} \\
\hline no vocational & 0.916 & $(0.117)$ & $* * *$ & -0.053 & $(0.013)$ & $* * *$ & -0.626 & $(0.953)$ & & 0.81 \\
\hline vocational & 0.799 & $(0.086)$ & $* * *$ & -0.048 & $(0.008)$ & $* * *$ & -0.237 & $(0.124)$ & $*$ & 0.98 \\
\hline high school & 0.830 & $(0.114)$ & $* * *$ & -0.065 & $(0.017)$ & $* * *$ & -0.380 & $(0.311)$ & & 0.97 \\
\hline university & 0.625 & $(0.109)$ & $* * *$ & -0.118 & $(0.021)$ & $* * *$ & -0.313 & $(0.104)$ & $* * *$ & 0.88 \\
\hline \multicolumn{11}{|c|}{ experience group 3 and 4} \\
\hline no vocational & 0.370 & $(0.116)$ & $* * *$ & -0.080 & $(0.015)$ & $* * *$ & -0.127 & $(0.028)$ & $* * *$ & 0.96 \\
\hline vocational & 0.293 & $(0.114)$ & $* * *$ & -0.073 & $(0.013)$ & $* * *$ & -0.103 & $(0.020)$ & $* * *$ & 0.95 \\
\hline high school & 0.358 & $(0.136)$ & $* * *$ & -0.075 & $(0.026)$ & $* * *$ & -0.117 & $(0.037)$ & $* * *$ & 0.94 \\
\hline university & 0.473 & $(0.101)$ & $* * *$ & -0.115 & $(0.037)$ & $* * *$ & -0.217 & $(0.069)$ & $* * *$ & 0.90 \\
\hline \multicolumn{11}{|c|}{ experience group 5 and 6} \\
\hline no vocational & 0.419 & $(0.118)$ & $* * *$ & -0.065 & $(0.015)$ & $* * *$ & -0.111 & $(0.023)$ & $* * *$ & 0.96 \\
\hline vocational & 0.401 & $(0.127)$ & $* * *$ & -0.057 & $(0.017)$ & $* * *$ & -0.095 & $(0.023)$ & $* * *$ & 0.87 \\
\hline high school & 0.455 & $(0.152)$ & $* * *$ & -0.088 & $(0.038)$ & $* *$ & -0.162 & $(0.056)$ & $* * *$ & 0.62 \\
\hline university & 0.294 & $(0.138)$ & $* *$ & -0.092 & $(0.035)$ & $* * *$ & -0.131 & $(0.041)$ & $* * *$ & 0.82 \\
\hline \multicolumn{11}{|c|}{ experience group 7 and 8} \\
\hline no vocational & 0.406 & $(0.125)$ & $* * *$ & -0.059 & $(0.014)$ & $* * *$ & -0.099 & $(0.018)$ & $* * *$ & 0.98 \\
\hline vocational & 0.179 & $(0.150)$ & & -0.064 & $(0.016)$ & $* * *$ & -0.078 & $(0.016)$ & $* * *$ & 0.96 \\
\hline high school & 0.358 & $(0.149)$ & $* *$ & -0.068 & $(0.054)$ & & -0.106 & $(0.076)$ & & 0.43 \\
\hline university & 0.300 & $(0.253)$ & & -0.058 & $(0.063)$ & & -0.083 & $(0.065)$ & & 0.86 \\
\hline
\end{tabular}

Notes: Dependent variable is $\ln w_{i j t}$, i.e. the $\log$ wage in each education-experience group. White-heteroscedasticity robust standard errors in parentheses. ${ }^{* * *},{ }^{* *},{ }^{*}$ denote the 1\%-, 5\%-, and 10\%-significance levels. The model is estimated by 2SLS. The unemployment rate is instrumented by its first, second and third lag. The model is specified as a one-way error component model with group specific fixed effects and contains a deterministic time trend and a squared deterministic time trend for each experience group. The regressions for each education-experience group are based on 44 observations, the regressions in each education group on 176 observations, and the overall regression on 704 observations. 


\section{Table 3: Impact of labor supply shocks on the capital-output ratio}

\begin{tabular}{lrrr} 
dependent variable: $\ln \kappa_{t}$ & model $(1)$ & model $(2)$ \\
\hline \multirow{2}{*}{$\ln \kappa_{t-1}$} & 0.850 & $* * *$ & $0.742 \quad * * *$ \\
& $(0.126)$ & $(0.095)$ & \\
$\ln N_{t}$ & 0.035 & & \\
& $(0.042)$ & \\
$\Delta \ln N_{t}$ & & -0.076 \\
& & $(0.070)$ \\
\hline & & \\
adjusted R & 0.611 & 0.615 \\
Durbin-Watson statistics & 1.468 & 1.388 \\
\hline \hline
\end{tabular}

Notes: White-heteroscedasticity robust standard errors in parentheses. ${ }^{* * *},{ }^{* *},{ }^{*}$ denote the 1\%-, 5\%-, and 10\%-significance levels. Each regression includes a constant and a deterministic time trend.

Table 4: Partial elasticity of native - foreign wages, $1 / \sigma_{i}$

\begin{tabular}{|c|c|c|c|c|c|c|c|c|}
\hline & \multicolumn{4}{|c|}{$1980-2004$} & \multicolumn{4}{|c|}{$1984-1993$} \\
\hline & \multirow{2}{*}{\multicolumn{2}{|c|}{$\begin{array}{r}\text { all workers } \\
1 / \sigma_{i} \\
\end{array}$}} & \multirow{2}{*}{\multicolumn{2}{|c|}{$\begin{array}{r}\text { weighted } \\
1 / \sigma_{i}\end{array}$}} & \multirow{2}{*}{\multicolumn{2}{|c|}{$\begin{array}{r}\text { all workers } \\
1 / \sigma_{i} \\
\end{array}$}} & \multirow{2}{*}{\multicolumn{2}{|c|}{$\begin{array}{r}\text { weighted } \\
1 / \sigma_{i}\end{array}$}} \\
\hline & & & & & & & & \\
\hline \multirow[t]{2}{*}{ all } & 0.060 & $* * *$ & 0.053 & $* * *$ & 0.073 & $* * *$ & 0.056 & $* * *$ \\
\hline & $(0.006)$ & & $(0.003)$ & & $(0.016)$ & & $(0.007)$ & \\
\hline \multirow[t]{2}{*}{ no vocational } & 0.084 & $* * *$ & 0.070 & $* * *$ & 0.076 & $* * *$ & 0.058 & $* * *$ \\
\hline & $(0.009)$ & & $(0.008)$ & & $(0.013)$ & & $(0.013)$ & \\
\hline \multirow[t]{2}{*}{ vocational } & 0.048 & $* * *$ & 0.051 & $* * *$ & 0.050 & $* * *$ & 0.054 & $* * *$ \\
\hline & $(0.004)$ & & $(0.004)$ & & $(0.007)$ & & $(0.008)$ & \\
\hline \multirow[t]{2}{*}{ high school } & 0.046 & $* * *$ & 0.050 & $* * *$ & 0.076 & & 0.131 & $* * *$ \\
\hline & $(0.016)$ & & $(0.014)$ & & $(0.048)$ & & $(0.034)$ & \\
\hline \multirow[t]{2}{*}{ university } & 0.071 & $* * *$ & 0.011 & & 0.113 & $*$ & 0.022 & \\
\hline & $(0.023)$ & & $(0.023)$ & & $(0.069)$ & & $(0.063)$ & \\
\hline observations & 800 & & 800 & & 320 & & 320 & \\
\hline$F$-test & 16.92 & & 9.30 & & 4.14 & & 5.64 & \\
\hline$p$-value & $0 \%$ & & $5 \%$ & & $39 \%$ & & $23 \%$ & \\
\hline
\end{tabular}

Notes: White-heteroscedasticity robust standard errors in parentheses. ${ }^{* * *}{ }^{* *},{ }^{*}$ denote the $1 \%-, 5 \%$, and $10 \%$-significance levels. Dependent variable is $\ln \left(w_{i j h t} / w_{i j f t}\right)$, i.e. the relative daily wage of native to foreign workers within the same educationexperience cell. The explanatory variable is the relative employment of native and foreign workers within the same education-experience cell. All regressions include education-by-experience group fixed effects. Observations in specification 2 are weighted by total employment in the cell. The $F$-statistic tests the Null hypothesis that all coefficients $1 / \sigma_{i}$ are identical across educational groups. 
Table 5: Partial wage elasticity across education-experience cells, $1 / \rho$

1980-2004

1984-1993

\begin{tabular}{|c|c|c|c|c|}
\hline & $\begin{array}{c}\text { CES-weighted } \\
\text { labor composite } \\
\text { (using estimated } \sigma_{i} \text { ) }\end{array}$ & $\begin{array}{l}\text { sum native and } \\
\text { foreign labor force } \\
\qquad\left(\sigma_{i} \rightarrow \infty\right)\end{array}$ & $\begin{array}{c}\text { CES-weighted } \\
\text { labor composite } \\
\text { (using estimated } \sigma_{i} \text { ) }\end{array}$ & $\begin{array}{l}\text { sum native and } \\
\text { foreign labor force } \\
\qquad\left(\sigma_{i} \rightarrow \infty\right)\end{array}$ \\
\hline $\ln L_{i j t}$ & $\begin{array}{r}0.031 \\
(0.006)\end{array}$ & $\begin{array}{r}0.031 \\
(0.006)\end{array}$ & $\begin{array}{r}0.064 \\
(0.016)\end{array}$ & $\begin{array}{r}0.063 \quad * * * \\
(0.016)\end{array}$ \\
\hline observations & 800 & 800 & 320 & 320 \\
\hline
\end{tabular}

Notes: White heteroscedasticity robust standard errors in parentheses. ${ }^{* * *}$, **, * denote the 1\%-, 5\%-, and 10\%-significance levels. Dependent variable is $\ln w_{i j t}$, i.e. the log daily wage in each education-experience cell. The equation is estimated by 2SLS using the log of employed foreign-born workers in the respective education-experience group as an instrument for the variable $\ln L_{i j t}$. All regressions include education by experience fixed effects and education by year fixed effects and time fixed effects.

Table 6: Partial wage elasticity across education cells, $1 / \delta$

1980-2004

CES-weighted sum native and labor composite foreign labor force (using estimated $\rho$ )

$$
(\rho \rightarrow \infty)
$$

1984-1993

CES-weighted sum native and labor composite foreign labor force (using estimated $\rho) \quad(\rho \rightarrow \infty)$

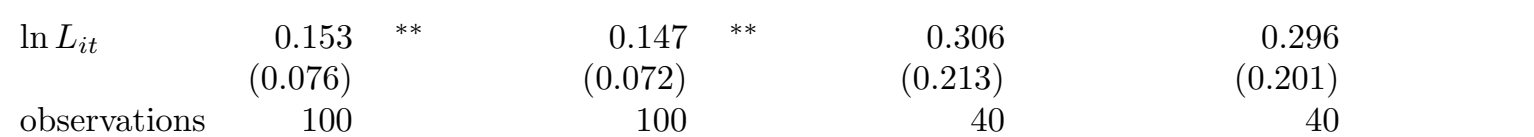

Notes: White heteroscedasticity robust standard errors in parentheses. ***, **, * denote the 1\%-, 5\%-, and 10\%-significance levels. Dependent variable is $\ln w_{i t}$, i.e. the log wage in each education cell. The equation is estimated by 2SLS using the log of employed foreign-born workers in the respective education group as an instrument for the variable $\ln L_{i t}$. All regressions include fixed time effects, education group fixed effects and education-specific time trends. 
Table 7: Simulation of migration effects on wages and unemployment

\begin{tabular}{|c|c|c|}
\hline & short-run results & long-run results \\
\hline $\begin{array}{l}\text { education } \\
\text { degree }\end{array}$ & $\begin{array}{l}\text { unemployment } \\
\text { rate }\end{array}$ & $\begin{array}{l}\text { unemployment } \\
\text { rate }\end{array}$ \\
\hline
\end{tabular}

wages: change in \% at an immigration of $1 \%$

unemployment rate: change in \%-points

total labor force

$\begin{array}{lrrrr}\text { all } & -0.04 & 0.05 & -0.00 & 0.01 \\ \text { no vocational } & -0.16 & 0.10 & -0.13 & 0.02 \\ \text { vocational } & 0.00 & 0.02 & 0.05 & 0.01 \\ \text { high school } & -0.14 & 0.24 & -0.11 & 0.17 \\ \text { university } & -0.05 & 0.03 & -0.01 & 0.01\end{array}$

native labor force

$\begin{array}{lrcrc}\text { all } & 0.02 & -0.00 & 0.06 & -0.01 \\ \text { no vocational } & -0.04 & 0.02 & -0.00 & 0.00 \\ \text { vocational } & 0.04 & -0.01 & 0.08 & -0.02 \\ \text { high school } & -0.06 & 0.03 & -0.02 & 0.01 \\ \text { university } & -0.04 & 0.01 & 0.00 & -0.00\end{array}$

foreign labor force

$\begin{array}{lllll}\text { all } & -0.58 & 0.32 & -0.55 & 0.12 \\ \text { no vocational } & -0.53 & 0.31 & -0.52 & 0.05 \\ \text { vocational } & -0.69 & 0.31 & -0.65 & 0.18 \\ \text { high school } & -1.53 & 1.32 & -1.54 & 0.71 \\ \text { university } & -0.21 & 0.09 & -0.17 & 0.05\end{array}$

Notes: The short-run simulations are based on the short-run semi-elasticities of the wage curve and consider the short-run impact of migration on the capital-output ratio. The long-run results are based on the long-run elasticities of the wage curve and a constant capital-output ratio. The effects have been calculated for natives and foreigners at each education-experience level separately. Aggregate wage figures are calculated by weighting each cell with the income share, aggregate unemployment figures by weighting each cell with the share in the labor force. 
Table 8: Simulation of migration effects: clearing labor markets

\begin{tabular}{|c|c|c|c|c|c|c|}
\hline \multirow[b]{2}{*}{$\begin{array}{l}\text { education } \\
\text { degree }\end{array}$} & \multicolumn{2}{|c|}{ all } & \multicolumn{2}{|c|}{ natives } & \multicolumn{2}{|c|}{ foreigners } \\
\hline & $\begin{array}{l}\text { short-run } \\
\text { results }\end{array}$ & $\begin{array}{r}\text { long-run } \\
\text { results }\end{array}$ & $\begin{array}{r}\text { short-run } \\
\text { results }\end{array}$ & $\begin{array}{l}\text { long-run } \\
\text { results }\end{array}$ & $\begin{array}{r}\text { short-run } \\
\text { results }\end{array}$ & $\begin{array}{l}\text { long-run } \\
\text { results }\end{array}$ \\
\hline & \multicolumn{6}{|c|}{ wages: change in $\%$ at an immigration of $1 \%$} \\
\hline all & -0.04 & -0.00 & 0.02 & 0.06 & -0.60 & -0.56 \\
\hline no vocational & -0.17 & -0.13 & -0.04 & -0.00 & -0.56 & -0.52 \\
\hline vocational & 0.01 & 0.05 & 0.04 & 0.08 & -0.70 & -0.66 \\
\hline high school & -0.16 & -0.12 & -0.07 & -0.03 & -1.65 & -1.61 \\
\hline university & -0.05 & -0.01 & -0.04 & 0.00 & -0.21 & -0.17 \\
\hline
\end{tabular}

Notes: Both simulations assume labor markets are perfectly flexible, i.e. that $\eta \rightarrow-\infty$. The short-run simulations consider the impact of immigration on the capital-output ratio, the long-run simulations assume a constant capital-output ratio. The effects have been calculated for natives and foreigners at each education-experience level separately. Aggregate wage figures are calculated by weighting each cell with the income share, aggregate unemployment figures by weighting each cell with the share in the labor force. 
Table 9: Simulation of migration effects, 1980-2004 and 1983-1993

\begin{tabular}{|c|c|c|c|c|}
\hline \multirow{3}{*}{$\begin{array}{l}\text { education } \\
\text { degree }\end{array}$} & \multicolumn{2}{|c|}{$1980-2004$} & \multicolumn{2}{|c|}{$1984-1993$} \\
\hline & $\begin{array}{r}\text { short-run results } \\
\text { unempl. }\end{array}$ & $\begin{array}{r}\text { long-run results } \\
\text { unempl. }\end{array}$ & $\begin{array}{r}\text { short-run results } \\
\text { unempl. }\end{array}$ & $\begin{array}{r}\text { long-run results } \\
\text { unempl. }\end{array}$ \\
\hline & wage & wages & wages & wages \\
\hline
\end{tabular}

wages: change in \%, unemployment rate: change in \%-points

total labor force

$\begin{array}{lrrrrrrrr}\text { all } & -0.12 & -0.03 & 0.00 & 0.09 & -0.18 & 0.41 & 0.00 & 0.17 \\ \text { no vocational } & 1.52 & -1.16 & 1.75 & -0.29 & -0.52 & 0.71 & -0.45 & 0.17 \\ \text { vocational } & -0.38 & 0.24 & -0.29 & 0.16 & -0.06 & 0.27 & 0.15 & 0.13 \\ \text { high school } & -4.34 & 3.86 & -4.45 & 2.77 & -1.13 & 1.63 & -1.08 & 1.06 \\ \text { university } & -1.38 & 0.47 & -1.29 & 0.32 & -0.19 & 0.28 & 0.02 & 0.16\end{array}$

native labor force

$\begin{array}{lrrrrrrrr}\text { all } & -0.01 & -0.04 & 0.10 & 0.00 & 0.06 & -0.02 & 0.24 & -0.11 \\ \text { no vocational } & 1.09 & -0.48 & 1.30 & -0.13 & -0.20 & 0.26 & -0.11 & 0.03 \\ \text { vocational } & -0.08 & 0.04 & 0.02 & 0.00 & 0.14 & -0.10 & 0.35 & -0.16 \\ \text { high school } & -2.66 & 1.59 & -2.73 & 0.97 & -0.17 & 0.19 & -0.05 & 0.05 \\ \text { university } & -1.23 & 0.38 & -1.15 & 0.23 & -0.10 & 0.04 & 0.11 & -0.05\end{array}$

foreign labor force

$\begin{array}{lrrrrrrrr}\text { all } & -1.17 & -0.27 & -0.97 & 0.38 & -2.93 & 2.63 & -2.89 & 1.44 \\ \text { no vocational } & 2.80 & -4.11 & 3.13 & -0.86 & -1.58 & 2.05 & -1.59 & 0.69 \\ \text { vocational } & -6.34 & 1.06 & -6.30 & 0.57 & -4.24 & 2.77 & -4.14 & 1.78 \\ \text { high school } & -32.01 & 4.21 & -32.86 & 2.10 & -17.56 & 8.78 & -18.63 & 5.49 \\ \text { university } & -3.23 & 0.37 & -3.15 & 0.21 & -1.59 & 0.83 & -1.39 & 0.42\end{array}$

Notes: The short-run simulations are based on the short-run semi-elasticities of the wage curve and consider the short-run impact of migration on the capital-output ratio. The long-run results are based on the long-run elasticities of the wage curve and a constant capital-output ratio. The effects have been calculated for natives and foreigners at each education-experience level and then aggregated. 
Table A1: Share of foreigners by education and experience

\begin{tabular}{|c|c|c|c|c|c|c|c|c|c|}
\hline education & experience & 1980 & 1984 & 1985 & 1990 & 1993 & 1995 & 2000 & 2004 \\
\hline \multirow[t]{9}{*}{ no vocational } & $0-5$ & 0.183 & 0.175 & 0.159 & 0.256 & 0.402 & 0.350 & 0.192 & 0.143 \\
\hline & $6-10$ & 0.278 & 0.187 & 0.199 & 0.227 & 0.360 & 0.413 & 0.334 & 0.213 \\
\hline & $11-15$ & 0.380 & 0.288 & 0.268 & 0.300 & 0.370 & 0.394 & 0.461 & 0.398 \\
\hline & $16-20$ & 0.459 & 0.352 & 0.340 & 0.345 & 0.397 & 0.421 & 0.418 & 0.470 \\
\hline & $21-25$ & 0.345 & 0.403 & 0.409 & 0.373 & 0.424 & 0.433 & 0.429 & 0.432 \\
\hline & $26-30$ & 0.228 & 0.262 & 0.293 & 0.410 & 0.418 & 0.435 & 0.444 & 0.422 \\
\hline & $31-35$ & 0.176 & 0.186 & 0.197 & 0.291 & 0.393 & 0.428 & 0.438 & 0.450 \\
\hline & $36-40$ & 0.081 & 0.118 & 0.128 & 0.183 & 0.226 & 0.258 & 0.388 & 0.450 \\
\hline & all & 0.242 & 0.224 & 0.229 & 0.280 & 0.349 & 0.376 & 0.402 & 0.397 \\
\hline \multirow[t]{9}{*}{ vocational } & $0-5$ & 0.030 & 0.026 & 0.027 & 0.049 & 0.093 & 0.121 & 0.094 & 0.062 \\
\hline & $6-10$ & 0.043 & 0.034 & 0.034 & 0.048 & 0.066 & 0.083 & 0.137 & 0.102 \\
\hline & $11-15$ & 0.074 & 0.052 & 0.052 & 0.064 & 0.077 & 0.081 & 0.105 & 0.150 \\
\hline & $16-20$ & 0.090 & 0.078 & 0.074 & 0.079 & 0.093 & 0.094 & 0.096 & 0.109 \\
\hline & $21-25$ & 0.057 & 0.078 & 0.085 & 0.088 & 0.094 & 0.102 & 0.106 & 0.105 \\
\hline & $26-30$ & 0.049 & 0.047 & 0.052 & 0.088 & 0.102 & 0.102 & 0.112 & 0.109 \\
\hline & $31-35$ & 0.037 & 0.044 & 0.045 & 0.054 & 0.074 & 0.092 & 0.110 & 0.114 \\
\hline & $36-40$ & 0.021 & 0.029 & 0.032 & 0.045 & 0.051 & 0.054 & 0.084 & 0.110 \\
\hline & all & 0.051 & 0.048 & 0.049 & 0.063 & 0.079 & 0.087 & 0.105 & 0.111 \\
\hline \multirow[t]{9}{*}{ high school } & $0-5$ & 0.039 & 0.019 & 0.021 & 0.020 & 0.033 & 0.051 & 0.064 & 0.049 \\
\hline & $6-10$ & 0.083 & 0.043 & 0.034 & 0.036 & 0.035 & 0.038 & 0.069 & 0.072 \\
\hline & $11-15$ & 0.117 & 0.097 & 0.087 & 0.056 & 0.056 & 0.050 & 0.055 & 0.077 \\
\hline & $16-20$ & 0.075 & 0.113 & 0.127 & 0.111 & 0.087 & 0.077 & 0.071 & 0.066 \\
\hline & $21-25$ & 0.084 & 0.088 & 0.084 & 0.150 & 0.144 & 0.126 & 0.090 & 0.080 \\
\hline & $26-30$ & 0.064 & 0.074 & 0.082 & 0.082 & 0.120 & 0.157 & 0.145 & 0.108 \\
\hline & $31-35$ & 0.030 & 0.061 & 0.065 & 0.074 & 0.085 & 0.096 & 0.164 & 0.144 \\
\hline & $36-40$ & 0.019 & 0.031 & 0.036 & 0.076 & 0.073 & 0.075 & 0.091 & 0.133 \\
\hline & all & 0.065 & 0.059 & 0.057 & 0.057 & 0.062 & 0.065 & 0.078 & 0.080 \\
\hline \multirow[t]{9}{*}{ university } & $0-5$ & 0.060 & 0.034 & 0.031 & 0.045 & 0.049 & 0.055 & 0.092 & 0.113 \\
\hline & $6-10$ & 0.084 & 0.052 & 0.046 & 0.040 & 0.049 & 0.046 & 0.044 & 0.081 \\
\hline & $11-15$ & 0.087 & 0.080 & 0.072 & 0.057 & 0.052 & 0.050 & 0.048 & 0.054 \\
\hline & $16-20$ & 0.078 & 0.081 & 0.083 & 0.087 & 0.073 & 0.067 & 0.057 & 0.056 \\
\hline & $21-25$ & 0.059 & 0.077 & 0.078 & 0.083 & 0.099 & 0.096 & 0.071 & 0.060 \\
\hline & $26-30$ & 0.050 & 0.053 & 0.054 & 0.076 & 0.074 & 0.085 & 0.098 & 0.076 \\
\hline & $31-35$ & 0.048 & 0.047 & 0.045 & 0.056 & 0.075 & 0.077 & 0.081 & 0.102 \\
\hline & $36-40$ & 0.025 & 0.028 & 0.049 & 0.042 & 0.045 & 0.050 & 0.047 & 0.063 \\
\hline & all & 0.071 & 0.062 & 0.059 & 0.061 & 0.063 & 0.063 & 0.062 & 0.070 \\
\hline
\end{tabular}

Notes: Individuals included in the sample are between 15 and 60 years old and are either employed or unemployed on September 30 of the respective year. 
Table A2: Daily wages of native workers by education and experience (constant 2000 Euros)

\begin{tabular}{|c|c|c|c|c|c|c|c|c|c|}
\hline education & experience & 1980 & 1984 & 1985 & 1990 & 1993 & 1995 & 2000 & 2004 \\
\hline \multirow[t]{9}{*}{ no vocational } & $0-5$ & 41 & 39 & 41 & 44 & 46 & 45 & 43 & 45 \\
\hline & $6-10$ & 55 & 54 & 54 & 57 & 59 & 60 & 57 & 58 \\
\hline & $11-15$ & 60 & 61 & 62 & 64 & 67 & 68 & 73 & 69 \\
\hline & $16-20$ & 62 & 62 & 64 & 68 & 70 & 70 & 76 & 78 \\
\hline & $21-25$ & 64 & 65 & 65 & 67 & 71 & 72 & 75 & 80 \\
\hline & $26-30$ & 64 & 66 & 67 & 69 & 70 & 71 & 78 & 77 \\
\hline & $31-35$ & 64 & 65 & 67 & 70 & 72 & 71 & 76 & 80 \\
\hline & $36-40$ & 63 & 65 & 66 & 70 & 71 & 72 & 77 & 76 \\
\hline & all & 60 & 61 & 62 & 65 & 68 & 69 & 71 & 72 \\
\hline \multirow[t]{9}{*}{ vocational } & $0-5$ & 49 & 48 & 49 & 53 & 56 & 56 & 58 & 59 \\
\hline & $6-10$ & 63 & 61 & 62 & 65 & 66 & 66 & 68 & 67 \\
\hline & $11-15$ & 72 & 72 & 72 & 74 & 76 & 76 & 79 & 78 \\
\hline & $16-20$ & 79 & 79 & 80 & 81 & 81 & 82 & 86 & 86 \\
\hline & $21-25$ & 81 & 84 & 85 & 86 & 86 & 86 & 89 & 90 \\
\hline & $26-30$ & 81 & 85 & 87 & 90 & 89 & 89 & 93 & 93 \\
\hline & $31-35$ & 81 & 84 & 87 & 92 & 93 & 93 & 96 & 96 \\
\hline & $36-40$ & 80 & 85 & 86 & 91 & 93 & 94 & 100 & 98 \\
\hline & all & 73 & 74 & 75 & 78 & 81 & 81 & 86 & 87 \\
\hline \multirow[t]{9}{*}{ high school } & $0-5$ & 58 & 57 & 57 & 61 & 64 & 65 & 68 & 68 \\
\hline & $6-10$ & 78 & 75 & 75 & 78 & 82 & 81 & 85 & 85 \\
\hline & $11-15$ & 92 & 93 & 94 & 93 & 95 & 95 & 104 & 102 \\
\hline & $16-20$ & 105 & 103 & 104 & 104 & 104 & 104 & 112 & 114 \\
\hline & $21-25$ & 112 & 114 & 114 & 109 & 109 & 109 & 114 & 115 \\
\hline & $26-30$ & 112 & 119 & 120 & 118 & 114 & 112 & 119 & 119 \\
\hline & $31-35$ & 117 & 127 & 126 & 120 & 123 & 120 & 125 & 121 \\
\hline & $36-40$ & 111 & 127 & 131 & 128 & 122 & 119 & 130 & 120 \\
\hline & all & 90 & 89 & 88 & 87 & 90 & 91 & 101 & 103 \\
\hline \multirow{9}{*}{ university } & $0-5$ & 87 & 92 & 92 & 94 & 96 & 93 & 105 & 95 \\
\hline & $6-10$ & 110 & 119 & 118 & 121 & 125 & 122 & 141 & 138 \\
\hline & $11-15$ & 129 & 141 & 144 & 137 & 144 & 144 & 160 & 168 \\
\hline & $16-20$ & 139 & 160 & 159 & 156 & 154 & 153 & 175 & 180 \\
\hline & $21-25$ & 143 & 166 & 166 & 166 & 168 & 166 & 181 & 186 \\
\hline & $26-30$ & 143 & 171 & 173 & 170 & 174 & 175 & 195 & 188 \\
\hline & $31-35$ & 139 & 171 & 170 & 177 & 179 & 177 & 204 & 199 \\
\hline & $36-40$ & 127 & 154 & 164 & 169 & 171 & 171 & 207 & 187 \\
\hline & all & 123 & 140 & 141 & 140 & 144 & 144 & 164 & 168 \\
\hline
\end{tabular}

Notes: Individuals included in the sample are between 15 and 60 years old, receive non-zero income and work at least on September 30 of the respective year. Wages are calculated in real Euro using the GDP deflator (base year: 2000). Wages above the social security ceiling are imputed. 
Table A3: Daily wages of foreign workers by education and experience (constant 2000 Euros)

\begin{tabular}{|c|c|c|c|c|c|c|c|c|c|}
\hline education & experience & 1980 & 1984 & 1985 & 1990 & 1993 & 1995 & 2000 & 2004 \\
\hline \multirow{9}{*}{$\begin{array}{l}\text { no vocational } \\
\text { degree }\end{array}$} & $0-5$ & 47 & 47 & 47 & 50 & 46 & 46 & 44 & 43 \\
\hline & $6-10$ & 58 & 56 & 57 & 59 & 56 & 55 & 55 & 53 \\
\hline & $11-15$ & 61 & 61 & 63 & 64 & 61 & 60 & 62 & 62 \\
\hline & $16-20$ & 65 & 63 & 64 & 66 & 63 & 64 & 65 & 66 \\
\hline & $21-25$ & 67 & 66 & 68 & 67 & 65 & 65 & 68 & 70 \\
\hline & $26-30$ & 67 & 67 & 68 & 71 & 67 & 66 & 68 & 70 \\
\hline & $31-35$ & 65 & 65 & 67 & 72 & 71 & 71 & 70 & 71 \\
\hline & $36-40$ & 64 & 64 & 65 & 70 & 70 & 70 & 74 & 74 \\
\hline & all & 63 & 62 & 64 & 67 & 64 & 64 & 66 & 68 \\
\hline \multirow{9}{*}{$\begin{array}{l}\text { vocational } \\
\text { degree }\end{array}$} & $0-5$ & 54 & 51 & 52 & 55 & 55 & 57 & 59 & 57 \\
\hline & $6-10$ & 63 & 61 & 62 & 65 & 62 & 63 & 67 & 67 \\
\hline & $11-15$ & 70 & 68 & 68 & 70 & 68 & 68 & 71 & 75 \\
\hline & $16-20$ & 74 & 73 & 75 & 73 & 70 & 71 & 74 & 75 \\
\hline & $21-25$ & 75 & 76 & 77 & 78 & 73 & 73 & 76 & 78 \\
\hline & $26-30$ & 74 & 76 & 77 & 81 & 78 & 77 & 76 & 78 \\
\hline & $31-35$ & 72 & 73 & 75 & 81 & 80 & 80 & 80 & 78 \\
\hline & $36-40$ & 71 & 73 & 75 & 77 & 79 & 80 & 84 & 82 \\
\hline & all & 70 & 70 & 72 & 74 & 71 & 71 & 74 & 76 \\
\hline \multirow{9}{*}{$\begin{array}{l}\text { high school } \\
\text { with vocational } \\
\text { degree }\end{array}$} & $0-5$ & 63 & 64 & 62 & 65 & 61 & 56 & 65 & 65 \\
\hline & 6-10 & 75 & 74 & 79 & 79 & 74 & 73 & 81 & 78 \\
\hline & $11-15$ & 78 & 78 & 76 & 92 & 82 & 81 & 87 & 90 \\
\hline & $16-20$ & 103 & 96 & 96 & 86 & 86 & 78 & 89 & 89 \\
\hline & $21-25$ & 92 & 103 & 108 & 97 & 78 & 85 & 86 & 88 \\
\hline & $26-30$ & 97 & 82 & 86 & 103 & 100 & 93 & 86 & 91 \\
\hline & $31-35$ & 102 & 99 & 141 & 90 & 93 & 85 & 101 & 85 \\
\hline & $36-40$ & 106 & 127 & 91 & 114 & 85 & 86 & 95 & 113 \\
\hline & all & 84 & 86 & 89 & 89 & 81 & 79 & 85 & 87 \\
\hline \multirow{9}{*}{$\begin{array}{l}\text { university } \\
\text { degree }\end{array}$} & $0-5$ & 97 & 107 & 119 & 109 & 102 & 105 & 115 & 107 \\
\hline & 6-10 & 114 & 127 & 135 & 124 & 140 & 132 & 135 & 141 \\
\hline & $11-15$ & 141 & 140 & 190 & 150 & 143 & 144 & 151 & 147 \\
\hline & $16-20$ & 135 & 157 & 172 & 153 & 152 & 157 & 149 & 164 \\
\hline & $21-25$ & 132 & 162 & 173 & 166 & 165 & 163 & 155 & 153 \\
\hline & $26-30$ & 138 & 149 & 167 & 175 & 162 & 189 & 151 & 173 \\
\hline & $31-35$ & 159 & 151 & 158 & 166 & 172 & 165 & 177 & 166 \\
\hline & $36-40$ & 134 & 191 & 147 & 149 & 185 & 151 & 175 & 212 \\
\hline & all & 126 & 144 & 164 & 150 & 150 & 151 & 147 & 151 \\
\hline
\end{tabular}

Notes: Individuals included in the sample are between 15 and 60 years old, receive non-zero income and work at least on September 30 of the respective year. Wages are calculated in real Euro using the GDP deflator (base year: 2000). Wages above the social security ceiling are imputed. 
Table A4: The wage curve: GMM-estimation results*

\begin{tabular}{|c|c|c|c|c|c|c|c|c|}
\hline \multirow[t]{2}{*}{$\begin{array}{l}\text { education } \\
\text { level }\end{array}$} & \multirow[t]{2}{*}{$\ln w_{i j, t-1}$} & \multicolumn{4}{|c|}{$\ln u_{i j t}$} & \multicolumn{2}{|r|}{$\begin{array}{l}\text { Wald- } \\
\chi^{2}(3) \text {-stat. }\end{array}$} & \multirow[t]{2}{*}{ obs. } \\
\hline & & \multicolumn{3}{|c|}{$1980-2004$} & & & & \\
\hline all ${ }^{1}$ & $\begin{array}{r}0.626 \\
(0.004)\end{array}$ & $* * *$ & $\begin{array}{r}-0.028 \\
(0.001)\end{array}$ & $* * *$ & $\begin{array}{r}-0.076 \\
(0.002)\end{array}$ & $* * *$ & 143786 & 736 \\
\hline no vocational ${ }^{2}$ & $\begin{array}{r}0.658 \\
(0.228)\end{array}$ & $* * *$ & $\begin{array}{r}-0.030 \\
(0.016)\end{array}$ & $*$ & $\begin{array}{r}-0.087 \\
(0.073)\end{array}$ & & 38 & 184 \\
\hline vocational $^{3}$ & $\begin{array}{r}0.775 \\
(0.082)\end{array}$ & $* * *$ & $\begin{array}{r}-0.035 \\
(0.009)\end{array}$ & $* * *$ & $\begin{array}{r}-0.155 \\
(0.070)\end{array}$ & $* *$ & 181 & 184 \\
\hline high school ${ }^{4}$ & $\begin{array}{r}0.653 \\
(0.195)\end{array}$ & $* * *$ & $\begin{array}{r}-0.044 \\
(0.007)\end{array}$ & $* * *$ & $\begin{array}{r}-0.127 \\
(0.075)\end{array}$ & $*$ & 60 & 184 \\
\hline university $^{5}$ & $\begin{array}{r}0.652 \\
(0.196)\end{array}$ & $* * *$ & $\begin{array}{r}-0.028 \\
(0.033)\end{array}$ & $* * *$ & $\begin{array}{r}-0.082 \\
(0.066)\end{array}$ & & 39 & 184 \\
\hline & & & $984-199$ & & & & & \\
\hline all $^{6}$ & $\begin{array}{r}0.452 \\
(0.006)\end{array}$ & $* * *$ & $\begin{array}{r}-0.041 \\
(0.000)\end{array}$ & $* * *$ & $\begin{array}{r}-0.075 \\
(0.001)\end{array}$ & $* * *$ & 21655 & 320 \\
\hline no vocational $^{7}$ & $\begin{array}{r}0.461 \\
(0.104)\end{array}$ & $* * *$ & $\begin{array}{r}-0.043 \\
(0.006)\end{array}$ & $* * *$ & $\begin{array}{r}-0.080 \\
(0.024)\end{array}$ & $* * *$ & 524 & 80 \\
\hline vocational $^{8}$ & $\begin{array}{r}0.732 \\
(0.054)\end{array}$ & $* * *$ & $\begin{array}{r}-0.043 \\
(0.007)\end{array}$ & $* * *$ & $\begin{array}{r}-0.162 \\
(0.049)\end{array}$ & $* * *$ & 363 & 80 \\
\hline high school ${ }^{9}$ & $\begin{array}{r}-0.937 \\
(0.778)\end{array}$ & & $\begin{array}{r}-0.055 \\
(0.006)\end{array}$ & $* * *$ & $\begin{array}{r}0.028 \\
(0.011)\end{array}$ & $* *$ & 127 & 80 \\
\hline university $^{10}$ & $\begin{array}{r}0.444 \\
(0.034)\end{array}$ & $* * *$ & $\begin{array}{r}-0.032 \\
(0.019)\end{array}$ & $*$ & $\begin{array}{r}-0.057 \\
(0.037)\end{array}$ & & 363 & 80 \\
\hline
\end{tabular}

Notes: The dependent variable is $\ln w_{i j t} .{ }^{*}$ Arellano-Bond (1992) two-step estimation. 1 The Sargan- $\chi^{2}(276)$-test statistics rejects the H0 of no over-identification with $31.8^{* * *}$. The Arellano-Bond $z$-statistics rejects the $\mathrm{H} 0$ of $\mathrm{AR}(1)$ at $-4.3^{* * *}$, and of $\mathrm{AR}(2)$ at 0.6. ${ }^{2}$ Sargan- $\chi^{2}(155)$-test statistics: $6.4^{* * *}$. Arellano-Bond $z-$ statistics: $\mathrm{AR}(1)-1.1, \mathrm{AR}(2) 0.4{ }^{3}$ Sargan- $\chi^{2}(155)$-test statistics: $6.7^{* * *}$. ArellanoBond $z$-statistics: $\operatorname{AR}(1)-2.2^{* *}, \operatorname{AR}(2)-2.1^{* *}$. ${ }^{4}$ Sargan- $\chi^{2}(155)$-test statistics: $6.3^{* * *}$. Arellano-Bond $z$-statistics: $\operatorname{AR}(1)-2.0^{* *}, \operatorname{AR}(2)-0.09 .{ }^{5}$ Sargan- $\chi^{2}(155)$-test statistics: $7.7^{* * *}$. Arellano-Bond $z$-statistics: AR(1) $-2.2^{* *}, \operatorname{AR}(2) 0.8 .{ }^{6}$ Sargan- $\chi^{1}(75)$-test statistics: $31.8^{* * *}$. Arellano-Bond $z$-statistics: $\operatorname{AR}(1)-3.0^{* * *}, \operatorname{AR}(2) 0.1 .{ }^{7}$ Sargan$\chi^{2}(64)$-test statistics: $7.6^{* * *}$. Arellano-Bond $z$-statistics: $\operatorname{AR}(1)-0.9, \operatorname{AR}(2)-1.2 .^{8}$ Sargan- $\chi^{2}(64)$-test statistics: $7.6^{* * *}$. Arellano-Bond $z$-statistics: $\operatorname{AR}(1)-2.2^{* *}, \operatorname{AR}(2)$ $-2.1^{* *}$. 9 Sargan- $\chi^{2}(65)$-test statistics $2.0^{* * *}$. Arellano-Bond $z$-statistics: $\operatorname{AR}(1) 1.3$, $\operatorname{AR}(2)$-0.4. ${ }^{10}$ Sargan- $\chi^{2}(65)$-test statistics $7.7^{* * *}$. Arellano-Bond $z$-statistics $\operatorname{AR}(1)$ $-2.2^{* *}, \operatorname{AR}(2)$ 0.2. GMM two-step standard errors are biased. 